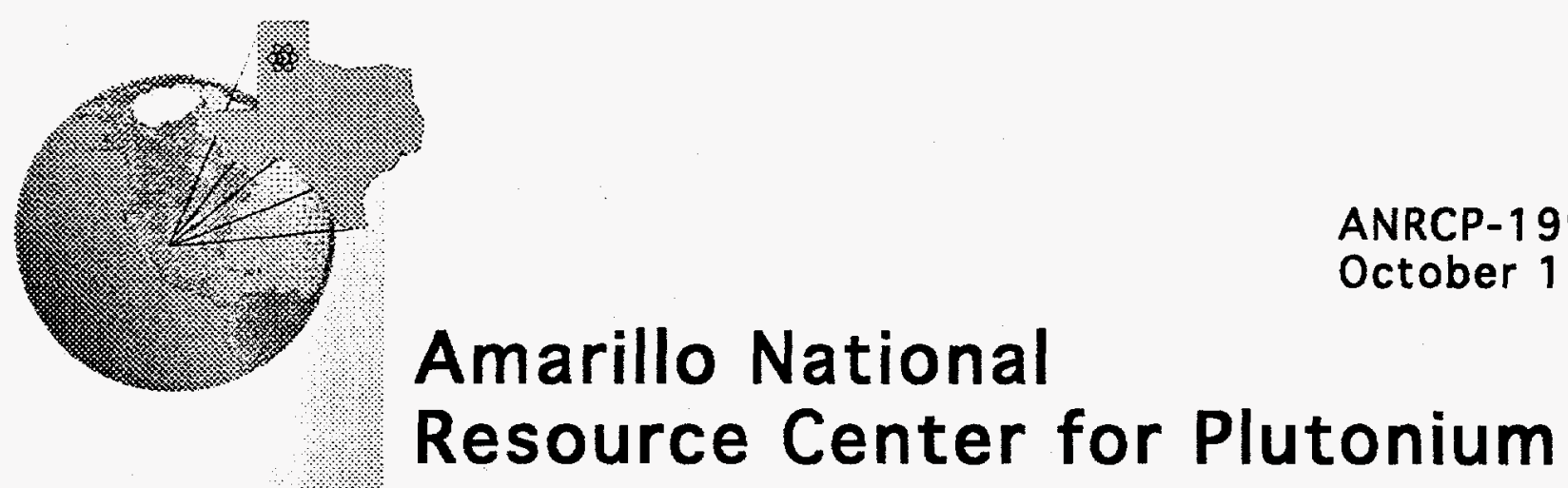

Amarillo National Resource Center for Plutonium

A Higher Education Consortium of The Texas A\&M University System, Texas Tech University, and The University of Texas System

\title{
U.S. Weapons-Useable Plutonium Disposition Policy: Implementation of the MOX Fuel Option
}

This report was prepared with the support of the U.S. Department of Energy (DOE), Cooperative Agreement No. DE-FC04-95AL85832

However, any opinions, findings. conclusions, or recommendations expressed herein are those of the author(s) and do not necessarily reflect the views of DOE. This work was con ducted through the Amarillo National Resource Center fop Plutonium.

\author{
Vanessa L. Gonzalez \\ Department of Political Science \\ Texas A\&M University
}

Edited by

Angela L. Woods

Technical Editor 


\section{DISCLAIMER}

This report was prepared as an account of work sponsored by an agency of the United States Government. Neither the United States Government nor any agency thereof, nor any of their employees, make any warranty, express or implied, or assumes any legal liability or responsibility for the accuracy, completeness, or usefulness of any information, apparatus, product, or process disclosed, or represents that its use would not infringe privately owned rights. Reference herein to any specific commercial product, process, or service by trade name, trademark, manufacturer, or otherwise does not necessarily constitute or imply its endorsement, recommendation, or favoring by the United States Government or any agency thereof. The views and opinions of authors expressed herein do not necessarily state or reflect those of the United States Government or any agency thereof. 


\section{DISCLAIMER}

Portions of this document may be illegible in electronic image products. Images are produced from the best available original document. 


\title{
AMARILLO NATIONAL RESOURCE CENTER FOR PLUTONIUM/
} A HIGHER EDUCATION CONSORTIUM

\author{
A Report on \\ U.S. Weapons-Useable Plutonium Disposition Policy: \\ Implementation of the MOX Fuel Option
}

\author{
Vanessa L. González \\ Department of Political Science \\ Texas A\&M University \\ College Station, Texas 77840
}

Submitted for publication to

Amarillo National Resource Center for Plutonium

October 1998 


\title{
US Weapons-Useable Plutonium Disposition Policy: Implementation of the MOX Fuel Option
}

\author{
Vanessa L. González \\ Department of Political Science \\ Texas A\&M University
}

\begin{abstract}
A comprehensive case study was conducted on the policy problem of disposing of U.S. weapons-grade plutonium, which has been declared surplus to strategic defense needs. Specifically, implementation of the mixed-oxide fuel disposition option was examined in the context of national and international nonproliferation policy, and in contrast to U.S. plutonium policy. The study reveals numerous difficulties in achieving
\end{abstract}

effective implementation of the mixed-oxide fuel option including unresolved licensing and regulatory issues, technological uncertainties, public opposition, potentially conflicting federal policies, and the need for international assurances of reciprocal plutonium disposition activities. It is believed that these difficulties can be resolved in time so that the implementation of the mixed-oxide fuel option can eventually be effective in accomplishing its policy objective. 


\section{ACKNOWLEDGMENTS}

Several individuals have contributed to the successful completion of this study. It is with great appreciation and respect that I acknowledge each of them here. I would first like to thank Dr. Lee Peddicord for his continued encouragement and support. His determination to see me succeed has been unfaltering. To Dr. Kim Hill, I extend my sincerest appreciation for his patient guidance and his willingness to help me develop a degree plan most appropriate for me. I am also grateful to Dr. James Anderson who has significantly contributed to my understanding of policy development and implementation. I would also like to recognize and thank $\mathrm{Mr}$. Roger Mulder of the State Energy
Conservation Office and the Governor's Pantex Program for his support of my work and research.

Additionally, I wish to acknowledge Dr. Charles A. Johnson and the Department of Political Science as well as the Department of Nuclear Engineering for contributions made to my graduate education. The Amarillo National Resource Center for Plutonium has also made significant contributions in support of this study and my graduate education.

This study and my graduate education could not have been completed without the support of my family. I thank my mom and dad for their unconditional love and encouragement; Roni, Val and Bella for comic relief; and Agapito for his support and for "my office." 


\section{TABLE OF CONTENTS}

ABSTRACT

ACKNOWLEDGMENTS .iii

1. INTRODUCTION 1

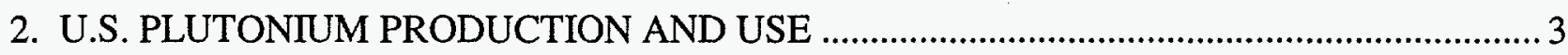

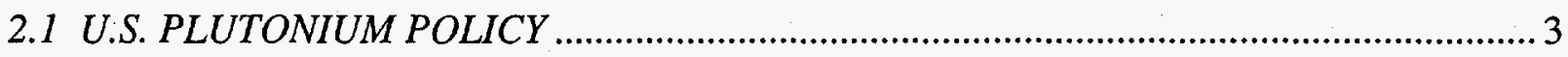

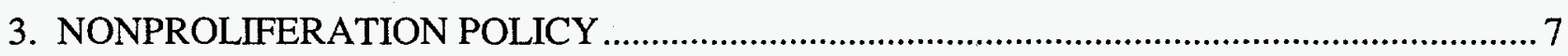

3.1 INTERNATIONAL NUCLEAR NONPROLIFERATION REGIME .................................... 7

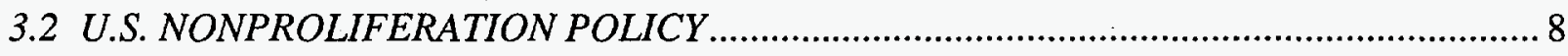

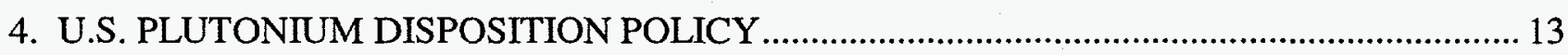

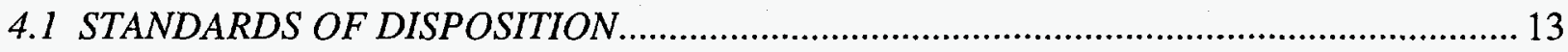

4.2 DOE'S ROLE IN PLUTONIUM DISPOSITION …….................................................. 14

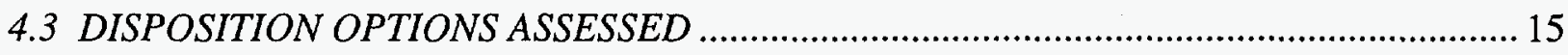

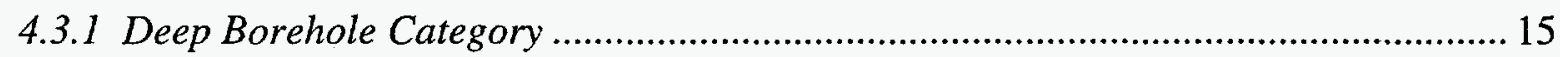

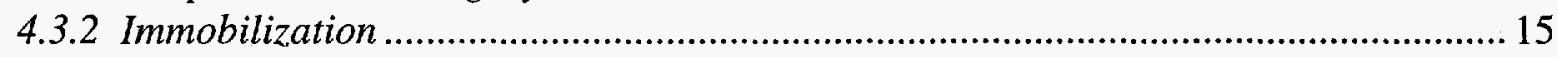

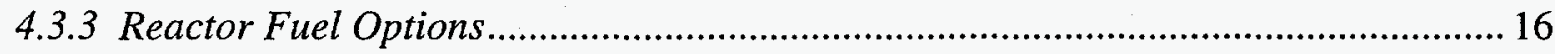

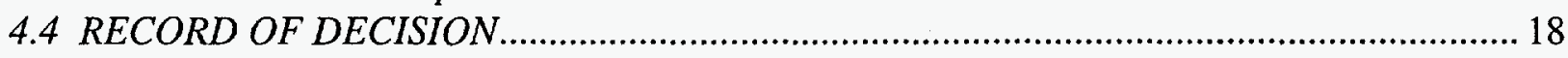

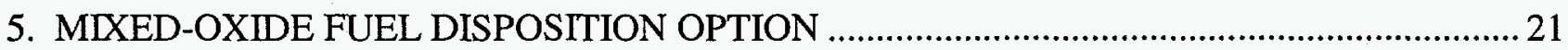

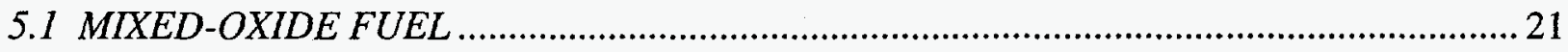

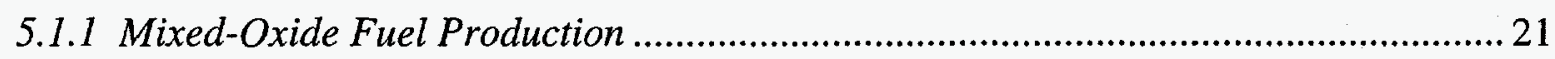

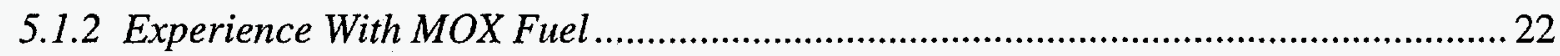

5.1.3 Gallium Removal .................................................................................................22

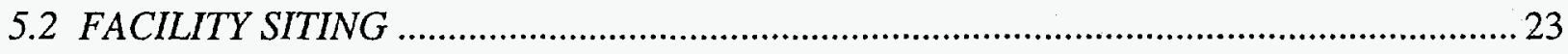

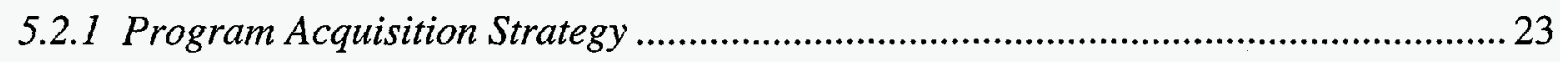

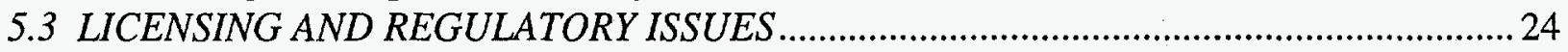

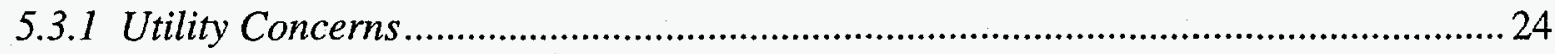

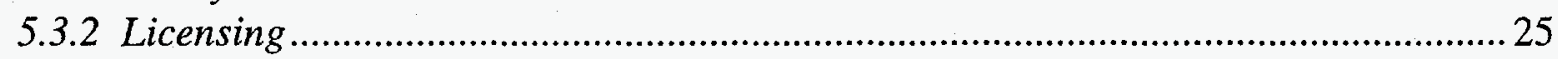

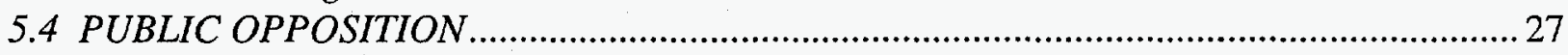

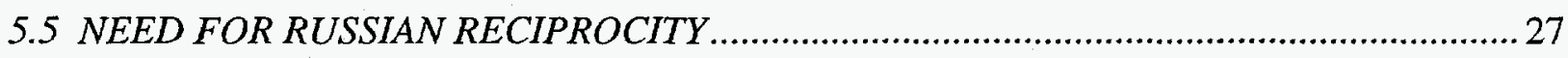

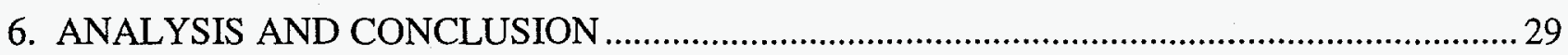

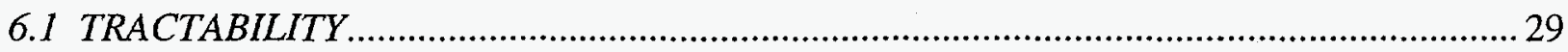

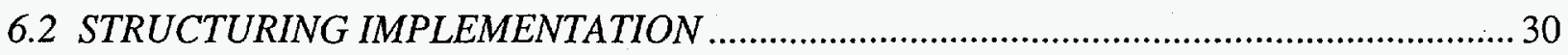

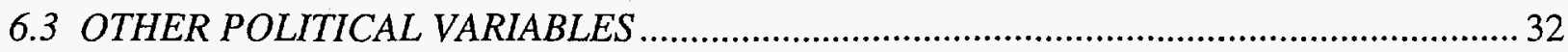

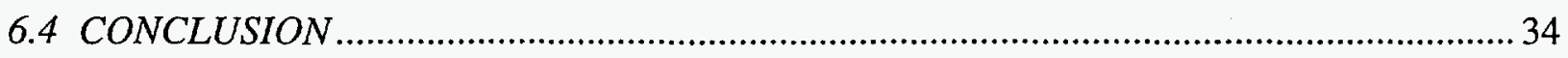

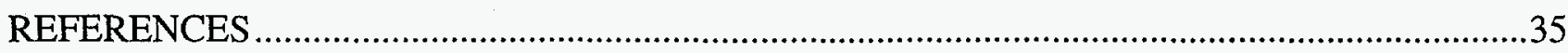




\section{INTRODUCTION}

On March 1, 1995, President Clinton declared 200 metric tons of weapons-useable fissile materials surplus to defense needs. Of this surplus, approximately 38 metric tons are weapons-grade plutonium. This material, and especially surplus weapons-grade material in the former Soviet Union, presents a significant threat to both national and international security. Through theft or diversion, these materials may result in the proliferation of nuclear weapons. This nuclear danger has heightened the need to safely and securely dispose of weapons-grade plutonium and has become a high priority of the U.S. plutonium disposition policy.

The primary objective of a weaponsgrade plutonium disposition program is to satisfy international nonproliferation policy by rendering surplus weapons-useable fissile materials inaccessible and unattractive for reuse in weapons. To this end, President Clinton directed the U.S. Department of Energy (DOE) to conduct a comprehensive review of long-term disposal options for weapons-grade plutonium. The final determination of the DOE review was to pursue a dual track disposition strategy. One track would be to immobilize a portion of the surplus plutonium in glass or ceramic material, the other would be to burn or irradiate a larger portion of the surplus plutonium as mixed-oxide fuel in existing commercial nuclear reactors.

The implementation of this policy decision, particularly as it involves the use of plutonium as fuel for nuclear reactors, is the focus of this study. Mazmanian and Sabatier (1983) identify three broad categories of variables, which should be considered in an analysis of policy implementation. These include the tractability of the problem, the availability of some authorizing statute to structure an effective implementation process, and the net effect of a variety of political variables in the balance of support for the policy objectives.

Successful policy implementation requires that a prescribed policy be manageable. Among the factors, which most often affect the tractability of a policy problem, are the prescribed behaviors, the size of the targeted group, and the extent of behavioral change required. An additional factor affecting tractability is that of technical difficulty.

The disposal of surplus weapons-grade plutonium poses many technical difficulties in accomplishing successful implementation. There remain several unresolved technical aspects of the plutonium disposition processes. Furthermore, the regulatory framework is not soundly in place and will likely require further legislation to resolve many uncertainties. However, efforts to provide assurances and solutions are ongoing and in time, these uncertainties can be resolved.

The second area of analysis involves the structuring of a favorable implementation process. This process relies significantly on the legislature and its authority to select the implementing institutions as well as legal and financial resources. However, in initiating new policies, the original policy authors can be most influential in structuring the implementation process by carefully delineating policy objectives and procedures.

In this case, the policy objective is concise and quite clear: to provide for the disposition of surplus weapons-grade plutonium in the interest of preventing nuclear weapons proliferation. This mission will be carried out until all weapons-grade plutonium, which has been officially declared excess to national defense needs, has been dispositioned through one of the two selected methods. Following completion of this mission, all use of mixed-oxide fuel in commercial nuclear reactors would cease. This leaves no 
ambiguity and little room for deviation from the prescribed process. While technical procedures and regulatory measures are yet unresolved, there is strong indication that this will be a well-structured policy.

The third area of analysis pertains to the net effect of political variables in establishing support for policy objectives. These variables include socioeconomic conditions; public support; attitudes of constituency groups; and, support from the legislature, the chief executive and the courts, as well as leadership of implementing agency officials. Each of these variables can contribute to the support of a policy and its effective implementation. However, the extent to which each of these political variables is important and necessary for successful policy implementation will vary. A primary political variable affecting implementation of the mixed-oxide fuel disposal option will be public support, or lack of it. As a rule, any new activity at a nuclear reactor site or major DOE nuclear facility generates local public interest and usually opposition. Although the DOE has recently made efforts to change and improve these attitudes, DOE's poor environmental track record will be difficult to overcome. Public cynicism over DOE nuclear activities results in close scrutiny and resolute resistance. Thus, the domestic political environment will pose some notable problems and hurdles for successful implementation.

Furthermore, previously declared federal policies with respect to the use of plutonium as fuel in commercial nuclear reactors may be construed as conflicting with the current proposed policy to use mixedoxide fuel. Additionally, the plutonium disposition policy is completely contingent upon the United States' ability to secure a bilateral agreement with Russia for reciprocal plutonium disposition activities. Thus, uncertainties about how to resolve these national and international policy issues will also slow or impede the implementation process.

The following chapters will elaborate upon these observations and provide a complete review of the nature of the plutonium disposition problem. Particular consideration will be given to the extraordinary measures that will need to be taken before the mixed-oxide fuel option may be fully implemented. Chapter 2 provides relevant background information as to the nature of the United States' production and use of weapons-grade plutonium over time as well as fluctuating policies with regard to the use of plutonium-based fuel in commercial reactors. Chapters 3 and 4 discuss nonproliferation policy and the related policy of weapons-grade plutonium disposal. Chapter 5 examines what will be required to implement the mixed-oxide fuel disposition option including new legislation, resolution of technical uncertainties, clarification of regulatory and licensing issues, public support, and assurance of Russian reciprocity. Finally, Chapter 6 considers the potential for effective implementation of the mixed-oxide fuel option according to indicators of policy tractability, the structure of the implementation process, and other political variables. 


\section{U.S. PLUTONIUM PRODUCTION AND USE}

Plutonium and highly enriched uranium (HEU) are the essential materials in nuclear weapons. The fissioning or splitting of the nucleus in these fissile materials produces the enormous amounts of energy released in an atomic bomb and can be used to ignite thermonuclear weapons. Plutonium and HEU were first produced in the 1940's by the United States and the Soviet Union as they launched their competing nuclear weapons programs (Albright, 1997). According to the U.S. Department of Energy, from 1944 to September 1994, the U.S. government produced and acquired a total of 111.4 metric tons of plutonium. In this same period of time, 12.0 metric tons of plutonium was removed, resulting in a U.S. inventory of approximately 99.5 metric tons of plutonium (U.S. Department of Energy 1996, hereafter USDOE).

Albright (1997) identifies four phases in the history of U.S. production of weaponsgrade plutonium. While any isotope of plutonium is "weapons-useable," the plutonium-239 isotope is the most suitable for nuclear weapons and is referred to as "weapons-grade." The first phase, what may be called the "expansionist phase," occurred from the mid-1940's to the mid-1960's (Albright 1997, 37). During this period, 14 plutonium production reactors were constructed and operated. Production of weapons-grade plutonium peaked in the early 1960 's at a rate of 6 metric tons per year. By 1965 , nearly 60 metric tons of weapons-grade plutonium had been accumulated.

The rate of plutonium production was nearly matched to the fabrication of nuclear warheads. Consequently, the production rate of plutonium began to decline as plutonium from retired nuclear weapons began to be recycled. This began the second phase from 1964 to 1972 , in which the production of weapons-grade plutonium gradually diminished to zero. Eight of the production reactors were closed and one, the $\mathrm{N}$ reactor at the DOE Hanford site in Washington, was reengineered to produce electricity at a minimum cost and consequently became a source of reactor-grade plutonium rather than weapons-grade.

While still minimal, the production rate increased to one metric ton of weaponsgrade plutonium per year during the third phase from 1973 to 1981. During this period, new warheads were being manufactured primarily from existing plutonium stocks or from recycled plutonium.

During the final phase of U.S. weapons-grade plutonium production, from 1982 to 1988 , the $\mathrm{N}$ reactor at the DOE Hanford facility returned to the production of weapons-grade plutonium. Several technological innovations enabled the production rate to double to 2 metric tons per year. This final phase began with ambitious plans to expand plutonium production due to the nuclear arms build up following the Soviet invasion of Afghanistan. However, by the . end of 1988, all U.S. plutonium production had ceased. Heightened concerns over reactor safety following the 1986 Chernobyl accident in the Soviet Union and improving relations between the East and West led to the shutdown of all remaining production reactors. The U.S. DOE announced in early 1991 that it had no further plans to produce plutonium.

\subsection{U.S. PLUTONIUM POLICY}

The history of U.S. plutonium in civilian use has also fluctuated. Twenty years ago when nuclear power was anticipated to expand rapidly, uranium fuel which is preferred for use in U.S. nuclear reactors, was expected to fall into short supply. These expectations enhanced the appeal of plutonium as an efficient, alternative, and 
economic fuel. In 1974, the Atomic Energy

Commission (AEC), predecessor of the Nuclear Regulatory Commission (NRC), produced a draft study of plutonium fuel in commercial light water reactors entitled, Generic Environmental Statement on the Use of Recycle Plutonium in Mixed Oxide Fuel in $L W R$ 's. The terms "plutonium recycle," "plutonium recycling" and "reprocessing" each refer to the chemical treatment of spent nuclear fuel to separate the plutonium for reuse from the unwanted radioactive waste byproducts. The AEC study predicted that the use of recycled or reprocessed plutonium could reduce the overall uranium requirement by 10 percent by 1990 (thereby reducing the impact on other natural energy resources when uranium fell into short supply as was expected). It also promised that the plutonium-based mixed-oxide fuel would reduce the radiological health impacts of nuclear fuel production. The study further concluded that the protection of plutonium against theft or sabotage was manageable and issued recommendations for regulatory licensing requirements (U.S. Atomic Energy Commission 1974, hereafter AEC). Two years later in 1976, the NRC published a similar study based on its environmental review of the health, safety and environmental aspects of the use of recycled plutonium in mixed oxide fuel in light water reactors. The study was entitled, NUREG-0002, Final Generic Environmental Statement on the Use of Recycle Plutonium in Mixed Oxide Fuel in Light Water Cooled Reactor. Its findings concurred with the conclusions of the previous study endorsing plutonium fuel as a preferred alternative to traditional uranium fuel.

These initial steps taken toward the wide-scale reprocessing of spent fuel and the use of recycled plutonium in the United States were stopped by the Ford and Carter administrations. The risk of proliferation of nuclear weapons became imminent in May 1974, when India detonated a nuclear device made with materials produced in its own plutonium reprocessing facility. In his statement on nuclear policy on October 28, 1976, President Ford stated, "the avoidance of proliferation must take precedence over economic interests....I have decided that the United States should no longer regard reprocessing of used nuclear fuel to produce plutonium as a necessary and inevitable step in the nuclear fuel cycle, and that we should pursue reprocessing and recycling in the future only if they are found to be consistent with our international objectives" (Shapar, 1995, USDOE 1997). The following year, President Carter went further to invoke nonproliferation measures by placing an indefinite ban on the commercial reprocessing and recycling of plutonium. In a statement on U.S. nuclear policy made on April 7, 1977, President Carter directed that, "We will make a concerted effort among all other countries to find better answers to the problems and risks of nuclear proliferation....First of all, we will defer indefinitely the commercial reprocessing and recycling of plutonium produced in U.S. nuclear power programs" (Shapar 1995).

The administrative resistance to plutonium reprocessing was reversed in October 1981, when President Reagan announced a series of policy initiatives including a lift on the indefinite ban of commercial plutonium reprocessing: “...we will pursue consistent, long-term policies concerning reprocessing of spent fuel from nuclear power reactors and eliminate regulatory impediments to commercial interest in this technology, while ensuring adequate safeguards" (Shapar, 1995).

However, by this time, new uranium sources were being discovered and the nuclear power industry's expansion had begun to slow, thereby diminishing plutonium's appeal as an economically viable alternative. Studies 
in 1994 suggested that the cost of fuel from plutonium was approximately $\$ 500$ per kilogram more than conventional uranium fuel, which was priced at $\$ 1,000$ per kilogram. This higher cost made electricity generated by plutonium fuel or mixed oxide fuel more expensive to produce and thus less desirable for commercial purposes in the U.S. (Hileman, 1994). However, there remained sufficient incentive for other countries-particularly Great Britain, France and Japan-to continue development of these plutoniumreprocessing technologies to ensure their individual energy independence (USDOE 1997).

Presidential opposition to plutonium reprocessing was resumed by President Clinton, although with somewhat more controversy and arguable ambiguity given the climate of nuclear arms reduction and disarmament, increasing declarations of surplus plutonium, and international debate over potential disposition options for excess nuclear weapons materials. In a statement released by the White House on nonproliferation and export control policy, President Clinton declared that, "The United States does not encourage the civil use of plutonium and, accordingly, does not itself engage in reprocessing for either nuclear power or nuclear explosive purposes. The United States, however, will maintain its existing commitments regarding the use of plutonium in civil nuclear programs in Western Europe and Japan" (Shapar 1995). These commitments to which President Clinton referred are the agreements between the U.S. and the European Atomic Energy Community (EURATOM) and between the U.S. and Japan. The U.S.-EURATOM Agreement that went into effect in April 1996, gives long-term programmatic consent to EURATOM countries to reprocess U.S. spent nuclear fuel and to recover plutonium for the production of electricity.
U.S. decisions on plutonium policy, although important, have had limited influence on world plutonium policies. A report published by the Congressional Research Service advised that countries already committed to using plutonium are not likely to stop because of U.S. opposition. Rather, economic factors and energy requirements have had and will continue to have greater impacts on shaping foreign plutonium policy. The report also suggests that countries actively engaged in plutonium production and the use of plutonium fueled reactors--notably France, Great Britain, Japan, Russia and India--may attempt to establish a global plutonium economy in which the U.S., under its current policy, could not be a participant (Davis and Donnelly 1994). In fact, despite the United States' efforts to curtail proliferation risks by opposing the reprocessing of spent fuel to recover plutonium, European countries have made great strides in plutonium reprocessing and mixed-oxide fuel fabrication technologies. The United States' limited influence in directing foreign plutonium policy has been a significant factor in the debate over disposal options for weapons-grade plutonium. 



\section{NONPROLIFERATION POLICY}

As nuclear production in both military and civilian arenas have expanded, the need for control and monitoring of these materials and related production technologies have become increasingly important to international security. As is observed by Hileman (1994, 12), "fissile materials outside warheads pose more security problems than those in intact weapons." As long as these fissile materials are contained within weapons, they remain heavily guarded within military complexes. Stringent military security measures may not necessarily be applied to these same materials once they have been extracted from weapons in fulfillment of international nuclear disarmament agreements.

This lack of security is of particular concern since the most difficult obstacle for rogue states or terrorists that want to manufacture nuclear arms is obtaining the necessary fissile materials. The expense and technological demands necessary for the development of nuclear facilities to produce highly enriched uranium and to reprocess spent fuel to obtain plutonium are generally adequate barriers to the development and proliferation of nuclear weapons. However, once these materials have been obtained in sufficient quantities, the task of designing and building a nuclear weapon has been well demonstrated.

Of the two primary fissile materials contained in nuclear weapons, highly enriched uranium (HEU) and plutonium, plutonium poses the greater proliferation risk. The HEU is diluted or "blended down" with the uranium-238 isotope, the main constituent of natural uranium, to make reactor fuel. This dilution is a relatively straightforward process. Re-enrichment of the uranium for re-use in weapons, however, is less easily accomplished. Sophisticated isotope separation techniques are required which few countries have developed. This is, therefore, a sufficiently effective technological barrier against HEU proliferation.

Plutonium does not lend itself to such a straightforward solution. Unlike uranium, both reactor-grade and weapons-grade plutonium are useable in weapons. Reactorgrade plutonium is produced as a by-product in spent fuel through the irradiation of uranium in reactors. Although less efficient in nuclear explosives and less easily manipulated due to increased radioactivity than the weapons-grade isotope of plutonium, reactor-grade plutonium can still be used to construct a formidable explosive. A simple bomb using reactor-grade plutonium can cause at least one-third of the destruction wrought by the Hiroshima weapon (Hileman, 1994). Therefore, plutonium in any isotopic form poses a significant proliferation risk. The conclusions reached in the 1996 Proliferation Vulnerability Red Team Report assert that the key to proliferation resistance is keeping plutonium inaccessible (Sandia National Laboratories, 1996). This has been the primary objective of the nonproliferation regime.

\subsection{INTERNATIONAL NUCLEAR NONPROLIFERATION REGIME}

The essence of the nonproliferation regime is captured in the text of a study produced by the National Academy of Sciences entitled Management and Disposition of Excess Weapons Plutonium. It reads, "Ultimately, restraining the spread of nuclear weapons is a political issue, which must rest on the conviction of states that their security is better served by not acquiring nuclear weapons" (National Academy of Sciences 1994, 49; hereafter NAS).

The nuclear nonproliferation regime is the combined international effort to contain the further spread of nuclear weapons. It is made up of treaties, international 
organizations, multilateral and bilateral agreements, and unilateral actions intended to prevent further proliferation. Major components of the regime include the Nonproliferation Treaty, the International Atomic Energy Agency (IAEA), the Nuclear Suppliers Group and the Zanger Committee, as well as various arms control agreements (Davis and Donnelly, 1995).

The foundation for international nonproliferation policy is the Nonproliferation Treaty (NPT) put into force in 1970 and extended indefinitely in May 1995. With more than 180 adherent countries, the treaty fundamentally represents a bargain. All member nations with the exception of the five nuclear powers: the United States, Great Britain, France, China and Russia, are prohibited by the NPT from acquiring nuclear weapons. In return, NPT provides that nonnuclear states are to have open access to and assistance in developing nuclear technology for peaceful purposes. Additionally, the treaty requires that nuclear states work toward disarmament while ensuring safeguards for nuclear materials (Albright, 1997, NAS, 1994, Davis and Donnelly, 1995).

The International Atomic Energy Agency (IAEA), created in Vienna in 1957, supplements the Nonproliferation Treaty. The IAEA conducts internationally agreed upon monitoring of civilian nuclear facilities to ensure safeguards of nuclear materials and the peaceful use of nuclear materials in nonweapon parties. Generally, the IAEA strives to ensure that commitments agreed upon in the NPT are honored by all Treaty members (Albright, 1997, NAS 1994, Davis and Donnelly, 1995).

The Nuclear Suppliers Group and the Zanger Committee serve to exercise control over the export and import of nuclear materials. The Nuclear Suppliers Group is an informal committee of nuclear supplier nations that maintains multilateral guidelines for nuclear exporting. The Zanger Committee is an NPT affiliate, which maintains a list of exported nuclear materials that must be safeguarded in the recipient state (Davis and Donnelly, 1995).

Finally, the five nuclear-weapon states under the NPT are required to work toward the control, reduction and disarmament of nuclear weapons. These efforts have produced multiple bilateral and multilateral arms control agreements. The Strategic Arms Reduction Treaty (START) I and START II which call for the drastic reduction of U.S. and Russian nuclear delivery systems, such as missiles and airplanes, by up to two-thirds have been signed and ratified (Boyle, 1998). Negotiation of a new START III began in the spring of 1997. START III would result in further reductions of U.S. and Russian nuclear arsenals. Within ten years of its ratification, the number of warheads in each arsenal would be down by 80 percent (Rankin and Hess, 1997). Another proposed agreement is the Fissile Material Cut-Off Treaty (FMCT). This is a multilateral arrangement proposed in the 1995 Nuclear Nonproliferation Treaty .... Review and Extension Conference. The U.S. has been a primary advocate for the FMCT which would prohibit the production of HEU and plutonium for nuclear explosives (Albright, 1997). More recently, arms control agreements have been signed that extend the deadline for conclusion of stockpile reductions called for in START II from the year 2003 to 2007 .

\subsection{U.S. NONPROLIFERATION POLICY}

U.S. nonproliferation policy consists of treaty commitments, informal undertakings, executive branch statements and actions, as well as statutory legislation. It imposes conditions and restrictions on U.S. nuclear exports and cooperation. The U.S. requires cooperative agreements with other nations before granting assistance in the 
development of nuclear technology. U.S. nuclear materials exporters must receive export licenses from the NRC. U.S. policy also maintains control over what a recipient state may do with nuclear materials and technology supplied by the United States (Davis and Donnelly, 1995).

The Atomic Energy Act (AEA) of 1954 and the Nuclear Nonproliferation Act (NNPA) of 1978 provide the foundation for U.S. nonproliferation policy. These acts acknowledge and emphasize the risks to national security posed by the potential proliferation of nuclear explosive devices. The NNPA directs the President to seek agreements with other nations and groups of nations to strengthen control, security and safeguarding of nuclear materials which have potential military applications (Davis and Donnelly, 1994).

Based on this legislation, U.S. policy requires non-cooperation with nations that violate nuclear agreements or non-nuclear weapon states that test nuclear explosives. This practice which essentially accepts plutonium use in some countries while opposing it in others, has met with some international dissatisfaction. Third world non-nuclear weapon states view the policy as discriminatory and resent limitations on their ability to gain access to more sophisticated nuclear technology for commercial purposes (Peddicord, 1995). Peddicord explains that, "Part of the problem is that the NPT stipulates that assistance will be provided to the weapon states by the non-weapon states to develop peaceful uses of atomic energy, but the nonweapon states feel that the weapon states, and especially the U.S., in their zeal to limit any proliferation, has reneged on this part of the NPT" (1998).

Nuclear cooperation agreements between the U.S. and the European Atomic Energy Community and between the U.S. and Japan in which the U.S. gives long-term consent to Europe and Japan to reprocess U.S. spent fuel and recover plutonium have spurred considerable controversy. In addition to the objections of non-weapon states, which, under the NPT, are restricted from reprocessing, members of nonproliferation groups and environmental coalitions argue that these agreements do not comply with provisions of the AEA or the NNPA. Indeed, such agreements are contrary to the United States' twenty-year resolve to provide leadership in international, nonproliferation policy by foregoing plutonium reprocessing.

These rifts in policy aside, U.S. nonproliferation policy has continued to increase in priority and salience. On September 27, 1993, President Clinton issued the U.S. Nonproliferation and Export Control Policy, which commits the United States to undertake a comprehensive management approach to the growing accumulation of fissile materials from dismantled nuclear weapons. This policy directs the United States to do the following:

- Seek to eliminate, where possible, accumulation of stockpiles of highly enriched uranium or plutonium, and to ensure that where these materials already exist they are subject to the highest standards of safety, security, and international accountability.

- Initiate a comprehensive review of long term options for plutonium disposition, taking into account technical, nonproliferation, environmental, budgetary and economic considerations. Russia and other nations with relevant interests will be invited to participate in the study. 
Additionally, President Clinton announced the submission of all U.S. fissile materials surplus to national defense needs to inspection by the IAEA and the intent to assist the former Soviet Union and other countries in the conversion of their HEU to peaceful purposes. These directives, announced before the United Nations, represent the broadest statement of national policy on surplus fissile material control and disposition (Curtis 1994).

During the Moscow Summit of January 1994, President Clinton and Russian President Yeltsin issued the Joint Statement between the United States and Russia on Nonproliferation of Weapons of Mass Destruction and Means of Their Delivery. In this joint statement, they declared the resolve of the two countries to cooperate actively and closely with each other, as well as other interested states, for the purpose of reducing and preventing nuclear proliferation threats by improving international safeguards and avoiding the accumulation of excess stocks of fissile materials. As part of this resolve, President Clinton and President Yeltsin agreed to establish a joint working group to consider steps necessary to ensure the transparency and irreversibility of the process of reduction of nuclear weapons, including the possibility of putting a portion of fissionable material under IAEA safeguards. In response to the January 1994 summit statement, a large team of U.S. and Russian experts convened and on September 6, 1996, produced the Joint United States/Russian Plutonium Disposition Study.

The current situation in the former Soviet Union suggests a variety of risks with respect to the management and disposition of nuclear weapons and fissile materials.

Because reciprocal policy commitment and progress are required before the U.S. and Russia will proceed with their fissile materials disposition programs, potential complications in Russian implementation of plutonium disposition must be considered and, if possible, avoided. The NAS study identifies three main categories of risk: "breakup," "breakdown," and "breakout" (NAS 1994, 4347). "Breakup" refers to the risks inherent to the current fragile state of affairs in which multiple nuclear-armed states have emerged where previously there was only one. Similarly, "breakdown" involves the erosion of government control over nuclear weapons materials within a particular state. This includes security and safeguard risks at every level from the diversion of materials and technology to the diversion of the expertise of now unemployed scientists. The third category of risks labeled "breakout," refers to the potential for Russia or any nuclear weapon state of the former Soviet Union to repudiate arms reduction agreements and resume maintenance of a larger nuclear arsenal.

These risks associated with the emergence of multiple nuclear-armed states where previously there was only one prompted the U.S. Congress to enact the Soviet Nuclear Threat Reduction Act on December 12, 1991. Known as the NunnLugar Cooperative Threat Reduction Program, this legislation provides for assistance to Russia in the safe, secure dismantlement of its nuclear weapons. In September 1993, the U.S. Department of Defense and the Russian Ministry of Atomic Energy signed an agreement for cooperation concerning the control, accounting, and physical protection of nuclear material. This was the implementing agreement of the NunnLugar program for assistance to Russia. Since 1991 , Congress has authorized more than $\$ 1.2$ billion to assist former states of the Soviet Union with safe and secure storage, transportation and dismantlement of nuclear weapons (NAS, 1994, Curtis, 1994).

U.S. nonproliferation policy has assumed five objectives: to secure nuclear weapons in the former Soviet Union; to 
ensure safe secure long-term storage and disposition of surplus fissile materials; to establish transparent and irreversible nuclear arms reductions; to strengthen the nuclear nonproliferation regime; and, to control nuclear exports (Spellman, Thomas, and Bugos, 1997; U. S. Department of Energy Office of Fissile Materials Disposition 1997, hereafter USDOE OFMD).

The objectives of nonproliferation policy in the United States are carried out by a network of federal organizations including: the National Security Council, the State Department, the Department of Defense, the Department of Commerce, the Central Intelligence Agency, the Arms Control and Disarmament Agency, the DOE, and the NRC. The DOE, through its Office of Fissile Materials Disposition has the lead role for evaluating technical options and developing analyses of economic, environmental, and other aspects of the potential disposition options. Its role and the role of the NRC in the implementation of nonproliferation policy through disposal of weapons-useable fissile materials will be discussed in greater detail in the following chapters. 



\section{U.S. PLUTONIUM DISPOSITION POLICY}

When President Clinton declared in 1995 that 200 metric tons of U.S. weaponsuseable fissile materials were surplus to defense needs, they became subject to the nation's plutonium disposition policy. Of this amount, approximately 165 metric tons are HEU and 38 metric tons are weapons-grade plutonium. An estimated total of 50 metric tons will be declared excess over the course of current nuclear arms reduction agreements. Some 10,000 to 20,000 warheads in the U.S. and a similar or greater number in the former Soviet Union have been declared surplus to national security needs (Spellman, Thomas, Bugos, 1997).

While plutonium and HEU are both used in nuclear weapons, there is greater concern over the disposition of plutonium. Primarily, this is because HEU can be diluted with other isotopes of uranium thereby producing low-enriched uranium (LEU) which is the most commonly used fuel in nuclear power reactors, including U.S. reactors. Re-enrichment of LEU requires complex technology that has not yet been developed in many countries or by most potential proliferators. Because LEU cannot sustain the chain reaction necessary for a nuclear explosion, it is not a significant proliferation risk. Conversely, plutonium cannot be diluted with other isotopes thereby making it ineffective for weapons-use. Any isotope of plutonium provides the necessary critical mass to induce a chain reaction for a nuclear explosive and, therefore, warrants maximum nonproliferation measures (NAS, 1994; Albright, 1997, 439.)

The need to dispose of weapons-grade plutonium in the interest of international security is paramount. In March 1992, Brent Scowcroft, then the National Security Advisor to President Bush, requested the National Academy of Sciences' Committee on
International Security and Arms Control to conduct a full-scale study of plutonium management and disposition options. The Clinton administration confirmed the Committee's mandate in January 1993. In their study, the National Academy of Sciences declared that the existence of excess plutonium and HEU "constitutes a clear and present danger to national and international security" (NAS, 1994,1). Of considerably greater concern than surplus materials in the U.S. is the surplus of these weapons-useable materials in the former Soviet states. These materials are at greater risk of theft or diversion. It is the urgency of this situation that has required a prompt policy response from the United States.

In order to minimize these risks, in September 1993, the U.S. Department of Defense and the Russian Ministry of Atomic Energy signed an agreement for cooperation concerning the control, accounting, and physical protection of nuclear material in Russia. This was the implementing agreement of the Soviet Nuclear Threat Reduction Act of 1991, which created the Nunn-Lugar Cooperative Threat Reduction Programs. Since 1991, the U.S. has expended $\$ 1.2$ billion through the Nunn-Lugar CTR programs to assist former states of the Soviet Union with safe and secure storage, transportation and dismantlement of nuclear weapons (NAS, 1994; Curtis, 1994).

\section{I STANDARDS OF DISPOSITION \\ Whether in Russia or the United} States, proliferation risks and threats to international security are prevalent in every aspect of nuclear weapons dismantlement and plutonium storage and disposition. The objective of any disposal policy is, therefore, not to eliminate risk since this an impossibility, but to maximally reduce risks. To this end, the National Academy of Sciences' study developed standards by which 
risks could be evaluated. The first is the "stored weapons standard" (SWS) (NAS, 1994). The Committee on International Security and Arms Control asserts that a surplus plutonium disposal option should incorporate the same standard of high security and accounting used in the storage of intact nuclear weapons. It is acknowledged that this standard is more difficult to apply to the various processing stages of any disposition option than it is to the simple storage of assembled weapons. However, the multiple procedural steps increase proliferation vulnerability making this standard that much more critical to preserve.

A second standard for the disposition of plutonium is the "spent fuel standard" (SFS). This standard requires that plutonium be made as inaccessible for use in weapons as is the plutonium produced in civilian spent fuel (reactor-grade plutonium) (NAS, 1994). The standard is actually a combination of characteristics such as size, weight chemical dilution of the plutonium, radiation, and, in some cases, isotopic degradation (U.S. Nuclear Regulatory Commission 1997a, hereafter USNRC). This last item, isotopic degradation of weapons-grade plutonium is not actually achieved through the immobilization option, so the U.S. does not see it as a requirement of the spent fuel standard. Russia does believe this is a necessary measure so that, as Howard Canter of the DOE Office of Fissile Materials Disposition pointed out, the spent fuel standard is really only a subjective measure (USNRC, 1997a).

The DOE has recently provided an additional requirement that the disposition option should not only leave the plutonium inaccessible, but also unattractive for re-use in weapons either by the host nation or others.

The scope of disposal options considered in the National Academy of Sciences study (NAS, 1994) was extensive and ranged from a space launch, in which plutonium would be launched into orbit around the sun, and remarkably, ocean dilution, which advocated the expulsion of plutonium into a large volume of water purportedly so that the plutonium would become so diluted as to meet safe drinking water standards.

Fortunately, these options were dismissed early on because of technical uncertainties, expense, and the impossibility of achieving public approval. Three disposal methods did receive strong support from the National Academy of Sciences: the deep borehole option, vitrification, and the mixedoxide fuel option. These constitute the three main categories of options later evaluated by the DOE and will be described in greater detail in the following sections.

\subsection{DOE'S ROLE IN PLUTONIUM DISPOSITION}

In response to President Clinton's 1993 nonproliferation policy announcement in which he directed that a comprehensive review of long-term disposal options for plutonium be considered, DOE Secretary Hazel O'Leary created a department-wide program for the control and disposition of surplus fissile materials. Later, in 1994, the DOE Office of Fissile Materials Disposition was created to ensure that this program was effectively carried out. Through the Office of Fissile Materials Disposition, the Department has the lead role for evaluating technical options and conducting formal studies of economic, environmental and other aspects of disposition options under consideration. The Office of Fissile Materials Disposition has the responsibility of complying with the National Environmental Policy Act.

Under the National Environmental Policy Act (NEPA), any major federal action that significantly affects the environment must be accompanied by an environmental impact 
statement (EIS). When an EIS has broad applications, it is called a programmatic environmental impact statement (PEIS). A PEIS was required for the federal plutonium disposition policy. To begin this federal rulemaking process, the acting federal agency issues a Notice of Intent (NOI). The NOI invites and initiates the "scoping" process, which involves gathering state and federal agency comments as well as public opinion to better define the issues that should be included in the analysis. The acting federal agency in this case is the DOE and the proposed action is the disposal of weaponsuseable plutonium.

On June 21, 1994, DOE issued an official NOI to prepare the Storage and Disposition of Weapons-Useable Fissile Materials Programmatic Environmental Impact Statement (S\&D PEIS). In March 1995 , DOE produced the summary report of a screening process. This report summarized the results of a study conducted to identify reasonable alternatives for long-term storage and disposition of surplus weapons-useable fissile materials. A total of 35 alternatives for plutonium disposition were identified. Four reactor-based plutonium disposition options, two borehole-type alternatives, and three plutonium immobilization alternatives were ultimately selected for serious review and consideration in the PEIS. The DOE, using its network of national laboratories, conducted detailed scientific studies of these nine options. The DOE published the S\&D Final PEIS in December 1996 (USDOE Office of Fissile Materials Disposition, 1996). It is the intent of the DOE that the disposition of surplus plutonium will serve as a nonproliferation and disarmament example for Russia and other nations.

\subsection{DISPOSITION OPTIONS ASSESSED}

In the S\&D PEIS, the DOE considered nine separate plutonium disposition options based on a comprehensive set of criteria, including each option's resistance to theft and diversion; resistance to retrieval and reuse; impact to human health and safety, and the environment; public and institutional acceptance; timeliness; technological viability; cost-effectiveness; international cooperation; and, additional benefits. In agreement with the National Academy of Sciences' findings, the options reviewed by DOE fell into three categories: deep borehole, immobilization, and reactor fuel.

\subsubsection{Deep Borehole Category}

Of the three categories of options given major consideration, the deep borehole method received the least enthusiasm and support. Under this disposal option, plutonium would be disposed of in deep boreholes that are drilled at least four kilometers (or two and half miles) into ancient, geologically stable rock formations beneath the water table. The deep borehole provides a geologic barrier against potential proliferation. The findings of the Nonproliferation and Arms Control Assessment of Weapons-Useable Fissile Material Storage and Disposition Alternatives confirm that the deep borehole option meets and even exceeds the spent fuel standard in its ability to deter recovery by subnational groups. However, accessibility and attractiveness are not sufficiently diminished to prevent and discourage recovery by the host nation. In this regard, the deep borehole options did not provide sufficient resistance to the retrieval and reuse of the plutonium.

In general, the two deep borehole alternatives were not leading options because of uncertainties regarding environmental impacts and technological feasibility. Additionally, the potential for U.S. retrieval and reuse in weapons would place a significant strain on efforts to achieve international cooperation. 


\subsubsection{Immobilization}

The two immobilization options, vitrification and ceramic immobilization, are very similar and involve the encasement of plutonium in a chemically stable form for disposal in a geologic repository, presumably in the Yucca Mountain high level waste repository which has not yet been approved. In order to increase the effectiveness of this option in meeting nonproliferation standards of inaccessibility and to achieve a radiation barrier, high level radioactive waste will be mixed with the plutonium before it is immobilized in either borosilicate glass or ceramic materials. A third immobilization option, electrometallurgical treatment, was reviewed, but will not be discussed here.

Vitrification has been the option most endorsed by the U.S. due to its effective elimination of proliferation risks. The general process of vitrification involves mixing plutonium with borosilicate glass and then melting the materials together and molding them into vitrified glass logs for placement in a geological repository. Similarly, ceramic immobilization would use ceramic materials rather than borosilicate glass to encase the plutonium. The U.S. plan would involve the addition of other highly radioactive wastes to the molten glass or ceramic mixture in order to further deter terrorists groups or rogue states from attempting to retrieve the vitrified plutonium (Hileman, 1994).

Either method of immobilization meets the "spent fuel standard" for nonproliferation which means that plutonium is processed and converted to a physical state that is as inaccessible and unattractive for reuse in weapons as plutonium in spent fuel. Additional advantages offered by the National Academy of Sciences include increased public approval for immobilization and relatively quick licensing (NAS, 1994).

However, this method also meets with opposition. The immobilization of plutonium in glass or ceramics is perceived by Russia and European nations having more than 20 years experience with plutonium-based fuel in nuclear reactors as a waste of a highly valuable energy resource. Furthermore, since the isotopic composition of weapons-grade plutonium is not altered through immobilization, Russia does not perceive this option as a satisfactory method of disposition. As in the case of the borehole option, since the weapons-grade plutonium would be fully recoverable from vitrification, it is perceived by Russia as a form of storage and not disposal. While Russia is intent on recovering some of its investment by making use of its plutonium in nuclear reactors, it would be difficult to convince Russia to go through with the disposition of its own plutonium in reactors and accept immobilization as a disposal method for U.S. plutonium. A major tenet of international nonproliferation policy and arms reduction agreements are irreversibility of the plutonium to weaponsuse, and immobilization disposition methods do not satisfy the Russian definition of irreversibility (Dimitriev, 1997).

There are additional problems with the immobilization options. While vitrification is a tried and proven technology, scientists are unsure about the possibility of plutonium undergoing a chain reaction during the melting process. It is believed that the plutonium may have a tendency to collect in pockets in the glass. It is also not known how the glass logs will age in a geologic repository and whether leaching may occur.

Furthermore, scientists are uncertain about the amount of plutonium that can be safely vitrified in one glass log, making the economic feasibility of large scale vitrification questionable (Hileman, 1994).

\subsubsection{Reactor Fuel Options}

In this category of disposal options, the spent fuel standard would be achieved by 
burning weapons-grade plutonium in nuclear reactors. It is important to note that a substantial fraction of plutonium remains in spent fuel so that the goal of the reactor disposition approach is not to destroy the plutonium, but to contaminate it with the highly radioactive fission by-products of spent fuel and to degrade the isotopic composition of the plutonium from weapons-grade to reactor-grade.

The process of the reactor fuel option involves the conversion of plutonium to plutonium-oxide. The plutonium-oxide is then mixed with uranium-oxide to produce a "mixed-oxide" (MOX) fuel. The technical feasibility of using MOX fuel is amply illustrated in Europe where experience with MOX fuel extends over 20 years.

Additionally, during the four years prior to the final S\&D PEIS, several studies of the reactor-based options were performed by reactor vendors regarding disposition of weapons-useable plutonium. The results of these early DOE sponsored studies showed that the use of excess weapons-grade plutonium to produce MOX fuel for nuclear power plants is technically feasible and promising for plutonium disposition. These findings were also confirmed by the National Academy of Sciences study (NAS 1994).

The four options considered in the S\&D PEIS for reactor disposition were use of the weapons-grade plutonium as MOX fuel in existing light water reactors, partially completed light water reactors, new evolutionary light water reactors and Canadian deuterium-uranium (CANDU) reactors. DOE identified the first of these, use of existing commercial light water reactors, as a preferred alternative in the S\&D PEIS. It also reserved the CANDU reactor option as a preferred alternative in the event that a multilateral agreement between Russia, Canada, and the U.S. could be reached. The remaining two reactor options would require design and/or construction of new reactors resulting in higher costs and increased difficulty in garnering public support. Therefore, only the preferred reactor options will be discussed here.

The option to burn plutonium in existing U.S. commercial reactors has the advantage over the immobilization and deep borehole options of ensuring international cooperation. Russia actively engages in plutonium reprocessing and is resistant to alternative disposition methods. Not only does Russia perceive plutonium as a highly valuable energy resource, but it is also intent on recovering at least a portion of its investment in the production of weaponsgrade plutonium.

Ironically, while the MOX fuel option enables the advancement of international nonproliferation policy through U.S. and Russian reciprocal disposition programs, it has been argued that it also contradicts U.S. nonproliferation policy. In the late 1970's, President Carter placed an indefinite ban on the reprocessing of plutonium for use in commercial nuclear reactors. The intent of. this ban was to set an example for other nuclear power countries and advance the international nonproliferation regime.

Although the United States' abstinence from plutonium reprocessing had a limited effect in curtailing foreign plutonium reprocessing, there is strong sentiment that enactment of the reactor fuel disposal option could serve to encourage civilian use of plutonium and weaken U.S. nonproliferation policy.

In a letter to Energy Secretary Hazel O'Leary, U.S. Representative Edward Markey of Massachusetts expresses deep concern over the compromise of U.S. nonproliferation policy should the MOX option be implemented. He warns that, "This would send a message to other countries that the United States tolerates mixing of its own military and civilian fuel cycles, thereby 
impairing the credibility of our efforts to discourage similar activities abroad." (Markey, 1997)

Public approval of reactor disposition options is also a problem. Strong anti-nuclear sentiment has been asserted with allegations that the MOX fuel option is the result of effective nuclear utility lobbying to reinvigorate the declining nuclear industry. Despite DOE assurances that MOX fuel fabrication facilities and reactors would only be operational until the disposition of surplus weapons-grade plutonium is complete, antinuclear environmentalists fear that this is merely the beginning of the reversal of the U.S. plutonium reprocessing policy.

Additionally, licensing and regulatory issues still need to be resolved. DOE has historically operated with no external regulatory oversight other than the Defense Nuclear Facilities Safety Board, which has no regulatory enforcement authority. However, the NRC has full regulatory oversight over every aspect of the civilian nuclear fuel cycle. In order for the DOE to dispose of weaponsuseable plutonium in commercial civilian nuclear reactors, the NRC will need to consider new licensing and operating standards. The DOE has recently begun to turn many of its activities over to the NRC for external regulation and has indicated that it would prefer to have the NRC also license and regulate the MOX fuel fabrication and reactor facilities. However, this will likely require action from Congress.

Under the CANDU reactor alternative, the MOX fuel containing surplus plutonium would be fabricated in a U.S. facility, then transported for use in a commercial heavy water reactor in Canada. The use of CANDU reactors would be subject to the policies, regulations, and approval of the federal and provincial Canadian governments. Pursuant to Section 123 of the Atomic Energy Act, any export of MOX fuel from the U.S. to Canada would require a cooperative agreement between the two countries.

One significant advantage to the CANDU alternative is that the spent fuel generated by a CANDU reactor would be the responsibility of the Canadian government and maintained within the Canadian spent fuel program. High level radioactive waste or spent fuel disposal in the U.S. has been an increasingly contentious problem that has not been resolved in nearly two decades.

The disadvantages to this option include concern over the long distances over which MOX fuel would need to be transported. This raises concerns over risks to human health and safety and the environment as well as increased risks of theft or diversion. Since it is unlikely that this option will be pursued without Russia, these same risks become extremely serious for Russian transportation of materials.

With regard also to other nonproliferation criteria including irreversibility of weapons-grade plutonium to weapons-use, the CANDU reactors produce smaller isotopic changes in the plutonium. Although this method does meet the spent fuel standard, the isotopic composition of plutonium in spent fuel from CANDU reactors remains closer to weapons-grade plutonium.

Also inherent to the CANDU alternative is the potential for complications regarding Canadian approval and licensing and Canadian public acceptance.

\subsection{RECORD OF DECISION}

Pursuant to procedures prescribed in the National Environmental Policy Act (NEPA) for federal decision-making, the DOE assumed the task of preparing an EIS. In February 1996, the Storage and Disposition of Weapons-Useable Fissile Materials Draft Programmatic Environmental Impact Statement was released and the scoping period 
was started. After a 92-day public comment period, the DOE had collected 8,442 comments from 6,543 individuals and organizations and 250 oral comments in addition to comments received from federal and state agencies (USDOE 1997). Following the comment period, the DOE published the S\&D Final PEIS in December 1996. A month later, the Record of Decision was issued. The final decision of the DOE with regard to the disposition of surplus plutonium was to pursue a "dual track" approach. According to this strategy, the DOE will pursue plans to immobilize a portion of the surplus plutonium in glass or ceramic material and burn a larger portion of the surplus plutonium as mixedoxide fuel in existing commercial nuclear reactors. The spent fuel produced from the MOX action would then be disposed of in the proposed high level radioactive waste geologic repository near Yucca Mountain in New Mexico. Additionally, the DOE reserved the option of sending MOX fuel to be burned in CANDU reactors in the event that a trilateral agreement between Canada, Russia and the U.S. could be reached. While research programs in conjunction with the Canadian federal government are underway in preparation for this contingency, this study focuses on plutonium disposition absent of such a trilateral agreement.

Both immobilization and MOX fuel options are necessary to achieve reciprocal disposition programs in Russia. The implementation of both disposition methods is also necessary since not all the plutonium is well suited for use as fuel. Approximately 30 percent of the total quantity of plutonium would require extensive purification before it could be used in MOX fuel. Such purification would be both costly and time consuming. Therefore, this plutonium is better suited for the immobilization option. In accordance with the DOE's Record of Decision, it will immobilize at least eight metric tons of currently declared surplus plutonium materials that is unsuitable for use in MOX fuel (USDOE 1997).

The advantage of the dual track approach is the increased efficiency of disposal. Should there be any significant delay or inability to carry out one of these options, the DOE will still be able to satisfy the nonproliferation requirement for timely, effective disposition by proceeding with the remaining option. The full extent to which either or both options are implemented will be determined by the results of technology demonstrations, additional environmental reviews and detailed cost proposals. The results of these efforts as well as nonproliferation concerns and negotiations with Russia will affect the timing and extent to which the disposal program is carried out.

With regard to the burning of excess plutonium as MOX fuel in existing civilian reactors, the DOE maintains that this decision is consistent with current U.S. nonproliferation policy because there will be no reprocessing or extraction of residual plutonium from the spent fuel. The spent fuel produced from the MOX fuel disposition effort will be disposed of pursuant to the Nuclear Waste Policy Act. Furthermore, the DOE insists that the MOX fuel will be fabricated in a domestic, DOE-owned and secured facility. The facility will be licensed and used only for the weapons-plutonium disposition mission and would be shut down upon completion of this mission. 



\section{MIXED-OXIDE FUEL DISPOSITION OPTION}

Many other decisions must be made before implementation of the mixed-oxide fuel option may be carried out. The DOE has still not determined where the necessary steps of the fuel option including pit disassembly, plutonium conversion and MOX fuel fabrication will take place. Licensing and regulatory issues remain unresolved. Action from Congress will likely be required to resolve potential conflicts between federal policies. Public opinion must be acknowledged and considered. And a bilateral agreement with Russia must be reached before the MOX fuel option may finally be implemented. Each of these considerations will be reviewed in this chapter.

\subsection{MIXED-OXIDE FUEL}

A basic understanding of the technological aspects of the MOX fuel disposition option will best illustrate the innate complexity of implementing such a policy. While this study concentrates on nontechnical issues surrounding the policy problem of implementing the MOX fuel option for plutonium disposition, the technical complexities cannot be wholly overlooked.

Uranium and plutonium are used as fuel in nuclear reactors. Unlike uranium, plutonium is not usually naturally occurring and is instead produced as uranium undergoes fission in nuclear reactors. The concentration of plutonium isotopes increases the longer plutonium is left in the reactor. By the end of the life of a commercial power reactor fuel assembly, it has been estimated that about 45 percent of the energy produced are from plutonium rather than uranium. Over the entire life of the fuel assembly, about 30 percent of the total energy produced came from plutonium fission. The residual uranium and plutonium can be recycled from the spent fuel while the fission products are disposed of as waste.

In countries such as Great Britain and France where MOX fuel is used, spent fuel is regularly reprocessed to recover plutonium and uranium for recycling. Alternately, since 1979, U.S. policy has been not to reprocess spent fuel in civilian light water reactors for commercial purposes.

\subsubsection{Mixed-Oxide Fuel Production}

The first step in the conversion of weapons-grade plutonium into mixed-oxide fuel is the disassembly of the plutonium sphere, called a "pit," which is extracted from a nuclear weapon. The plutonium is then converted to plutonium-oxide, which may be geologically disposed of through the immobilization option or used in the fabrication of mixed oxide fuel.

In MOX fuel fabrication, plutoniumoxide is mixed with uranium-oxide powder. The mixed-oxide powder is then compressed to form MOX pellets as seen in Figure 1. The pellets are sintered to increase the density and ground or polished to meet dimensional specifications. Each pellet is then visually inspected and selected for fuel rod fabrication. The MOX fuel rods are then fabricated into MOX fuel assemblies along with uraniumoxide fuel rods. MOX rods may comprise one-third of the full assembly. The assemblies are then placed in the reactor cores of nuclear power plants where they remain for three to four years. 


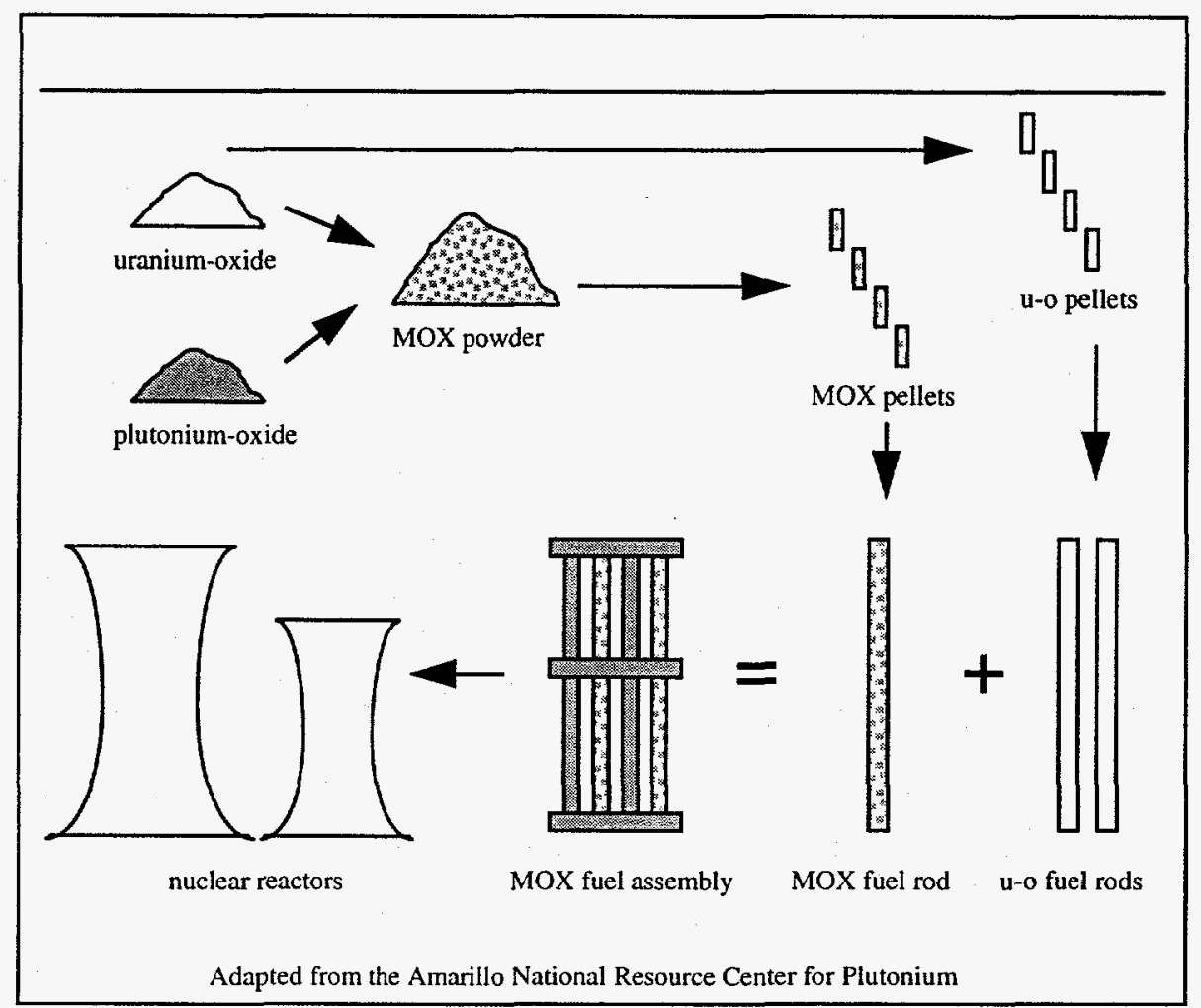

Figure 1: Mixed-Oxide Fuel Fabrication (González, 1996)

There is no commercial demand in the U.S. for MOX fuel. The purpose of using MOX fuel would be only to achieve nonproliferation and disposition goals. According to Dr. Lee Peddicord, if MOX fuel was used in existing reactors, complete disposition would take approximately 25 years assuming the use of three to seven reactors (González, 1996). Only reactors with long enough licensing periods to carry out the disposition program will be used. The length of time for disposition would also depend on the amount of MOX loaded in the fuel assembly. One-third MOX is commonly used, but use of full MOX cores may also be possible.

\subsubsection{Experience With MOX Fuel}

U.S. experience with MOX fuel is

limited. Fuel reprocessing and MOX use in civilian reactors ended in 1979 so that what little experience with MOX fuel that the U.S. had is significantly outdated. There is, however, extensive experience with MOX fuel worldwide. Belgium, France, and Great Britain have or are engaged in MOX fuel fabrication and use. Though not engaged in MOX fabrication, Germany, Sweden, Switzerland, Japan, and the Netherlands have also used or currently use MOX fuel.

\subsubsection{Gallium Removal}

The previous and ongoing experience with MOX fuel in European countries has not involved gallium, which was added to U.S. weapons-grade plutonium to increase machinability. There are variations between fabricating MOX fuel from weapons-grade plutonium and plutonium with greater fractions of the higher isotopes of plutonium, called reactor-grade plutonium. Plutoniumoxide from weapons-grade plutonium exhibits variations in physical characteristics such as surface area, mean particle size and morphology. Additionally, there are variations in isotopic content due to age or 
source of material (González, 1996). Other problems specific to MOX fabrication from weapons-grade plutonium are various impurities including gallium, which is present in all the plutonium pits at varying concentrations.

This is significant because it is imperative that the master blend of the mixedoxide fuel meets vendor specifications. Because gallium is present in varying concentrations in weapons-grade plutonium, failure to remove the gallium would require revisions of manufacturing and operations and could increase difficulties of licensing. Research has not yet produced a definitive conclusion about what level of gallium is unacceptable.

\subsection{FACILITY SITING}

An Environmental Impact Statement (EIS) is underway for the selection of sites to carry out the MOX fuel option. The draft EIS was issued in mid 1998. The EIS examines reasonable alternatives and potential environmental impacts for the proposed siting, construction and operation of three types of facilities for the implementation of the surplus weapons-grade plutonium disposition mission. The facility to implement the immobilization disposal option will not be considered here. Another facility will provide for the disassembly and conversion of the plutonium pits to plutonium-oxide. The candidate sites for this facility are the DOE Hanford Site in Washington; the Idaho National Engineering and Environmental Laboratory (INEEL); the DOE Pantex Plant in Amarillo, Texas; and the DOE Savannah River Site located in South Carolina. The third facility being considered is the mixed-oxide fuel fabrication facility. This facility would be located at one of the following DOE sites: the Hanford site, INEEL, Pantex, or the Savannah River Site. The extent to which the MOX option would be implemented will depend on a number of factors in addition to the environmental impacts addressed in the EIS. These factors would include cost considerations, contract negotiations and international agreements.

The final Surplus Plutonium Disposition Environmental Impact Statement and Record of Decision (ROD) are expected by the end of 1998 and January 1999 respectively. Opposition to particular site selections, perhaps in the form of court challenges, is expected to follow the ROD. For example, the Oregon state legislature has already taken preemptive measures against the selection of the Hanford site just miles from the Washington/Oregon border. Oregon House Bill 3640, signed into law July 25, 1997, expresses strong opposition to the use of the Hanford Nuclear Reservation for the processing of plutonium to fuel nuclear power plants. It further requests that the President of the United States and the Secretary of the U.S. Department of Energy continue with the policy of banning the use of plutonium to fuel commercial nuclear power plants (Oregon Congress, 1997).

\subsubsection{Program Acquisition Strategy \\ Once the sites have been selected,} DOE will require a fuel fabricator and a utility or number of utilities to carry out the MOX fuel mission. The selection of a fuel fabricator and utilities will be a competitive process. Rather than issuing requests for proposals, the DOE implemented a procurement strategy through which it has gained input from industry and addressed concerns in the current planning phase.

The strategy indicated a preference for awarding contracts to a consortium to be comprised, at minimum, of a fuel fabricator and an irradiation services provider, presumably a nuclear utility. The responsibilities of the consortium would be to design, construct, obtain a license for, and 
operate the fuel fabrication facility. The consortium would irradiate the MOX fuel in existing commercial reactors and would ultimately be responsible for the decontamination and decommissioning of the MOX fuel facility at the conclusion of the MOX fuel program (US NRC, 1997b).

The underlying assumption of this strategy is that the mission timetable for procurement of services and implementation of the program is dictated by international agreements with Russia. Dave Nulton of the Office of Fissile Materials Disposition emphasized that, "The United States isn't going to begin to eliminate or disposition [U.S.] plutonium until we see some commitment and progress on the Russian side as well." (US NRC, 1997b, 28) The extent to which agreements with Russia serve as a limiting factor in the U.S. implementation of the plutonium disposition program will be discussed in later sections of this study.

\subsection{LICENSING AND REGULATORY ISSUES}

The Atomic Energy Act of 1954 defines the legal authority of the NRC with respect to commercial and DOE activities. The DOE has historically operated with no external regulatory oversight other than the Defense Nuclear Facilities Safety Board, which only issues recommendations and has no regulatory enforcement authority (U.S. Congress, Office of Technology Assessment 1993; hereafter US OTA). The NRC has full regulatory oversight over every aspect of the civilian nuclear fuel cycle. However, the NRC does not generally have licensing authority over DOE facilities. In order for the DOE to dispose of weapons-useable plutonium in commercial, civilian nuclear reactors, it is logical that the NRC will need to be granted regulatory oversight authority over the MOX fuel fabrication facility. In fact, the DOE has recently begun to turn several of its activities over to the NRC for external regulation and has indicated that it would prefer to have the NRC also license and regulate the MOX fuel fabrication and reactor facilities. However, because the fuel fabrication facility will be government-owned and contractor-operated, there is uncertainty over whether the DOE will be required to be a co-licensee. If this is the case, legislation will definitely be required to grant NRC regulatory authority over DOE. In any event, some form of clarifying legislation will be necessary.

In an address before the Nuclear Energy Institute, Chairman Shirley Ann Jackson (Jackson, 1997b) noted the NRC's great interest in the MOX fuel program as it impacts three major areas regulated by the NRC: commercial nuclear power plants, fuel cycle facilities, and the high level radioactive waste disposal facility. She stated that, "After needed legislative clarification, the NRC intends to carry out our regulatory responsibilities in a manner that will avoid unnecessary delays or costs, but will be fully protective of public health and safety." Other more specific areas of needed legislation will be addressed throughout this chapter.

\subsubsection{Utility Concerns}

In the U.S., industry representatives have expressed reservations about the size and duration of the investment necessary for commercial nuclear power companies to participate in the MOX fuel program. The financial impact that could exist if unforeseen national or international events later prompted DOE to cancel the MOX program could be severe (Jackson, 1997a).

The concept of plutonium conversion is too new, and there are too many uncertainties about NRC licensing and public reaction for utilities to have set policies on this. However, several utilities are willing to consider this mission, especially if it aids in a 
national nonproliferation initiative (Andrews, 1996). Utilities simply want some assurances. Howard Canter (US NRC, 1997a, 5253) of the DOE Office of Fissile Materials Disposition noted that the assurances that utilities seek would best come from an international treaty, "...a lot of these uncertainties can be eliminated with legislation and, in fact, what I'd like to see is that the thing that drives this engine is an international treaty between us and the Russians. Even legislation is readily changed by the Congress. But the Congress is very reluctant to modify year to year something required by a treaty once they've ratified that treaty."

\subsubsection{Licensing}

It is desirable to have an NRC license for two primary reasons. The first has to do with gaining public approval. In recent years DOE has begun a number of initiatives to increase public participation in its decisionmaking and to facilitate public approval of its activities. One of these initiatives is the Memorandum of Understanding with the NRC to implement a two-year pilot program, unrelated to the plutonium disposition program, wherein NRC will assume regulatory authority over selected DOE facilities. The NRC licensing process and external regulation have value in satisfying the public's concerns and in building public trust. Secondly, NRC licensing is desirable because it is a tried and proven system. It is preferable to DOE to implement NRC's licensing system and keep the fuel fabricator and utilities in a regulatory framework with which they are already familiar.

However, there are some difficulties in having NRC involved. Prior MOX fuelrelated experience of NRC staff was gained through the development of the Draft Generic Environmental Statement on Mixed Oxide Fuel in the 1970's. NRC has not considered
MOX fuel since then and few NRC staff remain who worked on MOX fuel issues at that time.

Licensing and regulatory issues have been discussed in a series of meetings held at the NRC headquarters with various DOE program officials over the last few years. In these meetings, it was determined that use of MOX fuel in a nuclear reactor would require an amendment of the reactor operating since the technical specifications for fuel in most existing reactor licenses address only the use of low enriched uranium fuel (US NRC, 1995b).

A license amendment may be granted by NRC without a public hearing if the amendment is found to present no significant hazard; that is, if there is no significant increase in the probability or consequence of an accident previously analyzed in the license and if there is no significant reduction in the margin of safety. However, given public interest and concern over the matter of plutonium disposition in civilian nuclear reactors, NRC has cautioned DOE that a public hearing should be expected, regardless of whether license amendments present any significant changes in the probability of accidents (Curtiss, 1996; US NRC, 1995b).

NRC staff estimated that a hearing for a license amendment to allow a nuclear reactor to use MOX fuel could last an average of two years. However, because a license amendment regarding plutonium issues would be more contentious than typical reactor licenses and would likely draw official challenges to an NRC decision, NRC acknowledged that the process could take as long as five years (US NRC, 1995b).

Since there is virtually no experience with the MOX fuel fabrication facility hearing process, the time and effort required to successfully complete the process is expected to be long and extensive (Cliche, Badwan, Motley, 1997). NRC commissioners 
estimated that the license for a MOX fuel fabrication facility could reasonably take seven years for a new facility and five years for a modified, existing facility (US NRC, 1995b).

Also noteworthy is the potential for additional delays given objections from states and the public to the transportation of MOX fuel on interstate highways from the fabrication facility to reactor facilities. Depending upon where each process of the MOX option is sited, there would also be the possibility that plutonium-oxide would need to be transported from a plutonium conversion facility to the MOX fuel fabrication facility. The delays produced from the broad-based opposition to movement of plutonium on public byways would be considerable.

With regard to the licensing of facilities, NRC staff have noted that the licensing requirements would be the same for granting a license to existing or new facilities. However, NRC staff caution that licensing existing facilities, especially older ones, can be troublesome since the necessary documentation regarding facility design and construction may not be readily available. Such documentation provides evidence of the details of the construction necessary to make a finding regarding the safety of the facility. While records can often be reconstructed or developed by inspection or testing, NRC staff warned that the reconstruction of records and the design basis of a facility as it was constructed have been problematic for license applicants who have attempted such an activity. The costs associated with this effort to reconstruct records and the design basis of an existing facility can easily exceed the costs associated with simply designing and building a new facility. In either case, NRC requirements would be the same and NRC would review either kind of facility for full compliance.
Section 10, part 70 of the Code of Federal Regulations (10 CFR 70) which deals with the domestic licensing of special nuclear materials, such as plutonium, will provide the primary regulatory requirements for the MOX fuel plan (Williams ,1997; Cliche, Badwan, Motley, 1997). Consistent with 10 CFR 70, the NRC may approve construction of the principal structures, systems and components of a plutonium processing and fuel fabrication plant prior to approving a license to possess and use special nuclear material. These allowances are subject to change since regulations are being reviewed for revision. (Curtiss, 1996; US NRC, 1995a). Another licensing issue is that of transportation. Since DOE will be responsible for the transport of MOX fuel from the fuel fabrication facility to the reactor facility, both of which may be NRC licensed, it is unclear whether the transportation of the fuel should also be NRC licensed (US NRC, 1997a).

The issue of security measures is also unresolved with regard to licensing. Licenses issued by the NRC to utilities and fuel fabrication facilities do not permit the use of deadly force to protect materials. Since plutonium can be chemically separated from the uranium matrix, MOX fuel requires greater measures of protection. Under DOE rules, security measures to protect weaponsgrade nuclear materials include the use of deadly force. This disparity has been the source of much discussion among DOE officials, NRC officials, and potential industry participants. Since the MOX fuel fabrication will take place at a DOE facility, the current consensus is to have the MOX fuel fabrication facility fall under DOE provisions and the reactor sites under NRC jurisdiction, at least with regard to security measures. This, too, may require some clarifying legislation (US NRC, 1997b). 
Additional legislation may be required to codify the relationships between the PriceAnderson Act, the DOE, and the license holder for the MOX facility. The current proposal is to have the DOE indemnify the operator of the fuel fabrication facility and NRC cover the reactor facilities (Cliche, Badwan, Motley, 1997; US NRC, 1997b). If the fuel fabrication facility will be NRC licensed, legislation will be needed to allow DOE to indemnify an NRC licensed facility (Handwerker, 1997).

\subsection{PUBLIC OPPOSITION}

Despite DOE assurances that MOX fuel fabrication facilities and reactors would only be operational until the disposal of surplus weapons-grade plutonium is complete, anti-nuclear environmentalists fear that this is merely the beginning of the reversal of U.S. plutonium reprocessing policy. In response to this concern, DOE has made it clear that in selecting reactors to carry out the MOX fuel option, it prefers reactors whose current licenses will not require renewal or extension over the course of the plutonium disposition mission.

Howard Canter (US NRC, 1997a) of the Office of Materials Disposition stressed that DOE would not be advocating the renewals or extensions of any nuclear reactor licenses. "The decision on whether a reactor license gets renewed and its life extended is a commercial decision for the reactor owner and has to do with electric power production and other things and it should not be dependent upon this. We are not in this effort trying to solve the nation's energy problems." Should a reactor's license expire or require renewal before surplus weapons-grade plutonium disposal is completed, the immobilization option may be used as a fallback measure.

Furthermore, DOE is considering that at least one condition of the reactor license should be that it prohibits the possibility of using MOX fuel, purchased from Europe for example, after the DOE MOX fuel program has been completed or discontinued.

The regulatory environment that now exists in the United States affords multiple opportunities for opponents of nuclear projects to interact with regulatory agencies, the courts, and Congress to slow or stop their implementation (NAS, 1995, 382). Another way this might be said is that the regulatory process invites public participation. The cost of increased public participation is that the overall process of pursuing a large project through implementation, including the political process of gaining funding and approval, has become very difficult.

As a rule, any new activity at a nuclear reactor site or major DOE nuclear site generates local public interest and usually opposition. Although the DOE has recently made efforts to change and improve these attitudes, public cynicism over DOE's poor environmental track record will be difficult to overcome.

\subsection{NEED FOR RUSSIAN RECIPROCITY}

While the United States has an interagency process, which seeks to involve all relevant parties as early as possible to best ensure that technology and policy are consistent, Russia does not. The DOE has been required to seek involvement from the State Department, the Office of Science and Technology Policy, the National Security Council, and the NRC. No similar interagency cooperation or communication had been witnessed in Russia until recently. On July 23, 1997, Russian President Yeltsin created the Russian Interagency Standing Committee on Plutonium Disposition to oversee management of the disposition of excess weapons-grade plutonium. It is hoped that this effort will serve to expedite the process of achieving a bilateral agreement for 
the disposal of U.S. and Russian excess weapons-grade plutonium.

Howard Canter (US NRC 1997a, 56), of the DOE Office of Fissile Materials Disposition emphasized that, "If we can't get a deal negotiated with the Russians in eight or nine years, then I don't think we are going to do anything with our plutonium but store it...because we will never be able to sell up on the Hill spending a lot of money to do something with ours unilaterally."

The U.S. decision to implement both the immobilization disposition option and the mixed-oxide fuel disposition option was in large part due to Russian opposition to immobilization and its commitment to recover the costs of its nuclear weapons stockpile by recycling its weapons-grade plutonium for nuclear reactor fuel. As Russia was reluctant to agree to dispose of its plutonium unless the United States also embarked on a fuel option, which would result in the isotopic degradation of weapons-grade plutonium, the U.S. was forced to give serious consideration to the MOX fuel option. However, the U.S. will take no action without a bilateral agreement and some reciprocity. 


\section{ANALYSIS AND CONCLUSION}

A common conclusion in this increasingly complicated issue is that while disposition of plutonium is necessary, there is no urgency in establishing programs to achieve it. There has been strong sentiment that the disposal process should be drawn out over a 30 to 50 year time frame. A gradual approach to the disposition of plutonium is prudent given consideration of at least three important areas of effective policy implementation identified by Mazmanian and Sebatier (1983). These include the tractability of the problem being addressed, the ability of an authorizing statute to favorably structure the implementation process, and the net effect of a variety of political variables on the balance of support for policy objectives.

\section{I TRACTABILITY}

As it involves the disposal of nuclear materials using potentially new technologies and a new regulatory framework, and as it requires consideration of international policies, implementation of the mixed-oxide fuel option does not appear to be easily manageable. In considering the tractability of plutonium disposition through the mixedoxide fuel option, a first consideration is the technical difficulty of achieving the objective of disposal and ultimately plutonium nonproliferation.

As was briefly addressed in this study, many technical questions as to the conversion of plutonium to an oxide form and then to MOX fuel given the presence of gallium impurities are still being researched. Other difficulties relative to the technical uncertainties of the MOX fuel option are the regulatory and licensing problems, which will require time and legislative action in order to be resolved. Mazmanian and Sebatier (1983) point out that many programs are predicated on the availability or development of specific technologies. Disputes over the availability of a necessary technology provide strong pressures for delaying the achievement of policy objectives. Mazmanian and Sebatier (1983) suggest that additional indicators of the tractability of a given policy involve the diversity of the prescribed behavior, the size of the targeted group, and the extent of behavioral change required. While these indicators are less relevant to the issue of plutonium disposition than to social policies, an attempt is made here to evaluate U.S. plutonium disposal policy to use MOX fuel accordingly.

Mazmanian and Sebatier (1983) suggest that in social policy the more diverse the behavior being regulated, the more difficult it becomes to frame clear regulations and thus greater discretion must be allowed field-level policy implementors. This discretion may result in considerable variation in program performance and policy implementation. In this case, precise implementation procedures of the mixedoxide fuel plan will have been developed so that little or no discretion will be allowed at any level of the actual implementation process. In this regard, once the policy for MOX fuel use has been established, it should be quite tractable.

In general, the smaller or more definable a target group of a given policy whose behavior must be changed, the more likely it is that political support for the program can be mobilized. This measure is also less relevant here since there is no specifically targeted group. The plutonium disposal objectives are intended to provide for national and international security. It is an arguably necessary policy that will benefit all and be borne nearly undetectably by almost all.

Finally, the plutonium disposition policy is, for the most part, exempt from Mazmanian and Sebatier's final indicator for tractability which is the extent of behavioral 
change that a policy requires. There is little or no behavioral change required of the mass public in implementing the MOX fuel option. While gaining public acceptance in nuclear policy issues may be characterized as a behavioral change, the extent to which this behavioral change is necessary for policy implementation will vary. Although efforts are made to gain public support through information sharing and opportunities for public input, a highly vocal and organized minority will almost invariably remain unpersuaded and adamantly opposed to nuclear activities. The siting and location of the facilities, which will carry out the MOX fuel option, will undoubtedly produce some opposition. It is doubtful, however, that this opposition will be a significant deterrent to the implementation of plutonium disposition policy given resources already invested and the need for reciprocity with Russian plutonium disposition policy.

It may be concluded that the tractability of plutonium disposition policy to use MOX fuel hinges on uncertainties regarding technical procedures and the regulatory framework. However, ongoing technical research and increasing cooperation between the DOE and the NRC suggest that these uncertainties can and will be resolved in time. And this conclusion appears particularly reasonable in light of the long, time horizon over which the policy can be implemented.

\subsection{STRUCTURING IMPLEMENTATION}

The effectiveness of a policy is also determined by the structure of the policy implementation process. The basic argument provided by Mazmanian and Sebatier (1983) is that original policy makers can substantially affect the attainment of policy objectives by coherently structuring the implementation process. This involves the careful delineation of policy objectives, the selection of implementing institutions, the provision of legal and financial resources, and the regulation of opportunities for participation of non-agency actors in the implementation process.

Precise policy objectives are necessary because they provide unambiguous directives for implementing officials to follow and serve as resources for policy supporters. Plutonium disposition policy is strong on this point. As was described early in this study, the policy objective is both clear and concise: disposal of surplus weapons-grade plutonium in the interest of preventing the proliferation of nuclear weapons. To this end, two disposal options were selected for weapons-grade plutonium. These are immobilization and use of the plutonium in MOX fuel. This dual track approach was selected, in part, to ensure that in the event that one option would be delayed or prove infeasible, weapons-grade plutonium disposal could be carried out through the remaining disposal option. With regard to the MOX fuel option, the DOE decision makes clear that the use of plutonium in U.S. reactors would be limited to MOX fuel fabricated from weapons-grade plutonium designated as surplus to defense needs. Consistent with U.S. policy, which discourages the use of plutonium in civilian nuclear energy fuel cycles, there will be no reprocessing or subsequent reuse of spent MOX fuel and use of MOX fuel will cease upon completion of this mission.

Mazmanian and Sebatier (1983) also note the necessity of a valid causal theory for effective policy implementation. There must be an understanding of principal causal linkages between governmental intervention or activity and attainment of program objectives. The need for government intervention in the present case is to ensure national security against the threat of proliferation of nuclear weapons. It is then necessary to safely dispose of surplus 
weapons-grade plutonium. The use of surplus weapons-grade plutonium in MOX fuel is intended to achieve this end. As with almost any public policy, there is debate over the appropriateness of this particular action to achieve a solution to the problem. However, there is clearly a causal link between the problem, government response, and the prescribed program objectives.

Another important attribute of any policy statute is the extent to which implementing agencies are hierarchically integrated. This is determined by the number of veto or clearance points involved in the attainment of the prescribed objectives. Over the course of implementation of the MOX fuel option, the involved agencies will include the U.S. DOE, Office of Fissile Materials Disposition; the U.S. NRC, and to a lesser degree, possibly agencies of states where facilities will be located. The DOE is the implementing agency with oversight and regulatory authority expected to reside with the NRC. It is anticipated that the DOE will have adequate jurisdiction to carry out the plutonium disposition mission. Its selection of the dual track disposition approach in which both immobilization and mixed-oxide fuel disposition methods may be implemented provides the DOE with an added degree of flexibility to achieve the objectives of plutonium disposition policy. Should there be any significant delay or inability to carry out one of these options, the DOE will still be able to satisfy the nonproliferation requirement for timely, effective disposition by proceeding with the remaining option. Thus, it would appear that the number of agencies involved should not pose a substantial hurdle for implementation. But case studies of other historical policy efforts that require the cooperation of multiple agencies suggest that this conclusion should be made cautiously.
The decision rules of implementing agencies are also very important in the effectiveness of a policy. An authorizing statute can influence the implementation process by stipulating the formal decision rules of the implementing agencies. Discussion between DOE and NRC officials to determine necessary rules and regulations are continuing. Regulatory authority of NRC over DOE will require legislative clarification and should ensure that authority for all necessary rules for implementation ranging from fuel specifications, to transportation between facilities, to on-site security will be resolved and appropriately delegated.

Mazmanian and Sebatier (1983) strongly support the provision of formal access by program outsiders as necessary for effective policy implementation. They assert that statutes, which permit citizens to participate as formal intervenors in agency proceedings and as petitioners in judicial review, are more likely to have their objectives attained. The extent to which this assertion is true in this case of plutonium disposition is certainly debatable. Most organized public participation comes in theform of anti-nuclear activism and is perceived by policy implementors as disruptive and delaying rather than constructive.

However, formal access by program outsiders is available in this policy issue. NEPA provides for a federal decision-making process, which invites full public access and input and requires interagency cooperation in conducting comprehensive impact assessments of a proposed federal action. These assessments, called environmental impact statements (EIS), may be contested in a court of law and are subject to judicial review as to their adequacy. The EIS which is due to be released later this year and which will identify preferred sites and facilities for carrying out the plutonium disposition 
mission is expected to be challenged in such a way.

The NRC, which will issue facility licenses and enforce regulatory rules, has an open licensing process, which provides for public contesting of rules and decisions. Although the provision of formal access by the public creates additional delays and obstacles at multiple stages of implementation, open access has become a necessary feature for any nuclear-related policy. The nuclear industry as well as the DOE has earned poor reputations for management and safety practices, which were conducted for the most part, behind closed doors for many years.

While still early in the structuring stage of the weapons-grade plutonium disposal and MOX fuel implementation process, the preceding observations about implementation suggest that the implementation structure will provide for effective policy outputs. Again, uncertainties regarding decision rules, integration of implementing agencies, and formal procedures for allowing access by outsiders can be resolved as research and discussions continue.

\subsection{OTHER POLITICAL VARIABLES}

Aside from the legal structure of a policy, there are external forces, which have significant impacts on the effectiveness of policy implementation. These include the socioeconomic conditions and available technologies; public support; attitudes of constituency groups; support from sovereigns, such as the legislature and the chief executive and the courts; and the level of commitment and leadership skill of implementing officials. The extent to which implementation of the MOX fuel option is still being planned limits the discussion on each of these important variables. However, an attempt is made here to consider the impacts of each one at present and to speculate on future effects.

Variations in socioeconomic conditions affect the political support for statutory objectives. This, in turn, affects the outputs of implementing agencies and the achievement of policy objectives. These variations in conditions can affect the perceived importance of the problem addressed by a statute or policy decision. Other policy problems may become more important over time so that political support for allocating resources to the original statute would likely diminish. This is a definite possibility in the implementation of plutonium disposition policy, which is expected to span two to three decades or more. During this time, any number of events may occur that could affect the perceived importance of plutonium disposition and, particularly, the methods of disposal.

However, short of abandoning international nuclear disarmament agreements and nonproliferation policies, it is difficult to imagine what future event would interfere with the implementation of a plutonium disposition program. Historically, nationalsecurity measures have received ample political and public support. As long as plutonium exists, which is on the order of several thousands of years, it will pose a significant threat to national and international interests in the nonproliferation of nuclear weapons. Therefore, implementation of the plutonium disposition options should continue to warrant a high level of support despite changes in socioeconomic conditions.

Support for the manner in which weapons-grade plutonium is disposed might fluctuate given changes in socioeconomic conditions, or more likely, advancements in technology over time. It is difficult to speculate how support for immobilization or the MOX fuel option may change over time. However, it would be reasonable to assume 
that there would not be deviation from these specific disposition methods given the considerable investment that will have been made in terms of research and expertise, regulatory standards developed, infrastructure, and international agreements with Russia. Generally speaking, any new activity at a nuclear reactor site or major DOE facility generates local public interest and usually opposition. As has been stated, this is the result of poor safety and management track records. Although openness initiatives have been enacted to foster public support, there remain considerable cynicism and suspicion on the part of the public. Therefore, achieving public support as an important factor in effective policy implementation continues to be a significant challenge. Numerous community watchdog groups, national environmental coalitions, and antinuclear activists have mobilized to oppose implementation of the mixed-oxide fuel option. Fearful that this option will strengthen the nuclear energy industry and result in an eventual reversal of the U.S. plutonium reprocessing policy, these groups have organized a wide range of opposition efforts. They have issued various studies opposing MOX fuel, convened large antiMOX fuel conferences, and launched letterwriting campaigns. The Alliance for Nuclear Accountability, the Institute for Energy and Environmental Research, the Nuclear Information and Resource Service, Physicians for Social Responsibility, and the Safe Energy Communication Council even united to designate a day as "International NIX MOX Action Day."

It is unlikely that this activity is representative of the larger, general public. Rather, it is clear that anti-nuclear activism is well organized in the United States, as well as internationally. While it has been effective in forcing DOE and the nuclear industry to increase their efforts to provide access to information and opportunities for public participation, there is no indication that it will impede the implementation of the DOE decision to carry out the MOX fuel option for plutonium disposition. DOE claims that this decision is necessary to achieve Russian reciprocal weapons-grade plutonium disposal.

Mazmanian and Sebatier (1983) assert that in addition to the public, support from sovereigns is necessary for effective policy implementation. Sovereigns, who include the legislature, the chief executive, the courts, and other supervisory governmental entities, provide support for statutory objectives through the amount and direction of oversight, the provision of financial resources, and the extent of subsequent mandates. The disposal of weapons-grade plutonium has not yet formally entered this arena so that such support is difficult to describe. It should be noted that any support or lack of support among the sovereigns today may change by the time that this policy is ready for authorization and implementation.

Changes of political actors over time are also important to consider in assessing the level of commitment and leadership skill among implementing officials. This is the final indicator of effective policy implementation which Mazmanian and Sebatier (1983) identify. They assert that this indicator includes an ability of implementing officials to develop good working relationships with sovereigns, to convince opponents and target groups that they are being treated fairly, to mobilize support among constituencies, and to use the mass media effectively to present the agency's case for a particular policy or program. As was previously discussed, the clearly defined policy objectives and implementation procedures associated with the plutonium disposition mission may diminish the need for this particular effectiveness criterion. The plutonium disposition program will see many 
changing-of-the-guards before it is completed and so should not rely too heavily on individual leadership. Since the initial notice of intent in 1994 to produce the Storage and Disposition of Weapons-Useable Fissile Materials Final Programmatic Environmental Impact Statement, DOE has been under the direction of two agency executives and is now seeing a new replacement with the third secretary of the DOE.

It is too early to conclude whether these additional political variables imply effective policy implementation of the mixedoxide fuel option. Public support, or lack of it, may prove to be problematic in achieving support from sovereigns and other constituency groups.

However, Mazmanian and Sabatier (1983) point out that not all these conditions, nor even a majority of them, are typically met in the early stages of implementation. Given that there is ample time to sort out uncertainties, respond to public concerns, and develop institutional supports, the eventual implementation of the mixed-oxide fuel option for the disposal of weapons-grade plutonium is feasible.

\subsection{CONCLUSION}

The present case study considers the policy problem of disposing of surplus U.S. weapons-grade plutonium and implementation of the mixed-oxide fuel disposal option. There are numerous difficulties in achieving effective implementation of the mixed-oxide fuel option including unresolved licensing and regulatory issues, technological uncertainties, public opposition, potentially conflicting federal policies, and the need for international assurances of reciprocal plutonium disposition activities.

Despite these challenges to policy tractability, the structuring of a favorable policy implementation process, and to obtaining political support in its various forms, effective implementation of plutonium disposition policy is possible. The necessary gradual approach to the development and implementation of plutonium disposition policy allows for time to work through and diminish these challenges. It is believed that disposal of U.S. weapons-grade plutonium through use of mixed oxide fuel can eventually be carried out successfully. 


\section{REFERENCES}

1. Albright, David. 1997. Plutonium and Highly Enriched Uranium, 1996: World Inventories, Capabilities and Policies. New York: Oxford University Press Inc.

2. Andrews, Warren M. 1996. "Plutonium Protection and Management." Panel presentation at the International American Nuclear Society Meeting, Washington, DC.

3. Boyle, David. 1998. Texas A\&M University, Department of Nuclear Engineering. Interview.

4. Cliche, Carl E., Faris Badwan, and Frank E. Motley. 1997. Nuclear Regulatory Commission Considerations for Licensing a Mixed Oxide Fuel Fabrication Facility. Los Alamos, CA: Los Alamos National Laboratory. LA-UR-97-1442.

5. Curtis, Charles B. 1994. "Presidential Nonproliferation and Export Control Policy." Testimony before the Committee on Armed Services Military Application of Nuclear Energy panel on the Department of Energy's plans for surplus fissile material control and disposition.

6. Davis, Zachary S., and Warren H. Donnelly. 1994. "U.S. Plutonium Policy." Washington, DC: Congressional Research Service, Library of Congress. IB93102.

7. Davis, Zachary S., and Warren H. Donnelly. 1995. "Nuclear Nonproliferation Policy Issues in the 104th." Washington, DC: Congressional Research Service, Library of Congress. IB91023.
8. Dimitriev, Alexandre M. 1997.

"Regulatory Issues Related to Plutonium Disposition." Presented at meeting of state regulators, Austin, Texas.

9. González, Vanessa L. 1996. Summary of the Mixed Oxide Fuel Meeting for Texas Regulators. Austin, TX: State Energy Conservation Office. SECO-PTX-96-01.

10. Handwerker, Alan. 1997. "Program Acquisition Strategy." Presented at the Program Acquisition Strategy Workshop, Argonne, IL.

11. Hileman, Bette. 1994. "U.S. And Russia Face Urgent Decisions On Weapons Plutonium." Chemical \& Engineering News 72(24): 12-25.

12. Jackson, Shirley Ann. 1997a. "Sharing Regulatory Perspectives: The Nuclear Regulatory Commission in a Time of Change." Presented at the 22nd Annual Symposium of the Uranium Institute, United Kingdom.

13. Jackson, Shirley Ann. 1997b. "Nuclear Energy and Economic Competition: The NRC Perspective." Presented at the Nuclear Energy Institute Fuel Cycle '97 Conference, Atlanta, Georgia.

14. Markey, Edward J. 1997. U.S. Congress. House. Personal correspondence. 14 January.

15. Mazmanian, Daniel A. and Paul A. Sabatier. 1983. Implementation and Public Policy. Glenview, IL: Scott Foresman and Company.

16. National Academy of Sciences. Committee on International Security and Arms Control. 1994. Management and 
Disposition of Excess Weapons

Plutonium. Washington, DC: National

Academy Press.

17. National Academy of Sciences. Committee on International Security and Arms Control. 1995. Management and Disposition of Excess Weapons Plutonium: Reactor Related Options. Washington, DC: National Academy Press.

18. Oregon Congress. 1997. Enrolled House Bill 3640. 69th Oregon Legislative Assembly, Regular Session.

19. Peddicord, Kenneth L. 1995. Texas A\&M University, Department of Nuclear Engineering. Interview.

20. Rankin, Robert, and David Hess. "New Missile Talks are a Breakthrough." San Jose Mercury News, 25 March 1997, sec. Editorial.

21. Sandia National Laboratories. 1996. Proliferation Vulnerability Red Team Report. Sandia, NM: Sandia National Laboratories.

22. Shapar, Howard. 1995. "The Policy of the United States with Respect to the Reprocessing of Spent Fuel." Presented at the annual meeting in France.

23. Spellman, D. J., J. F. Thomas, and R. G. Bugos. 1997. History of the U.S. Weapons-Useable Plutonium Disposition Program Leading to DOE's Record of Decision. Oak Ridge, TN: Oak Ridge National Laboratory. ORNL/TM-1341.

24. U. S. Atomic Energy Commission. Directorate of Licensing - Fuels and Materials. 1974. Summary and
Conclusions. Vol. 1 of Generic Environmental Statement Mixed Oxide Fuel. Washington, DC: Atomic Energy Commission.

25. U.S. Congress. Office of Technology Assessment. 1993. Dismantling the Bomb and Managing the Nuclear Materials. 103d Congress, OTA-O-572.

26. U.S. Department of Energy. 1996. Plutonium: The First 50 Years. Washington, DC: Department of Energy.

27. U.S. Department of Energy. Office of Fissile Materials Disposition. 1996. Storage and Disposition of WeaponsUseable Fissile Materials Final Programmatic Environmental Impact Statement. Washington, DC: Department of Energy.

28. U.S. Department of Energy. 1997. Factsheet: Surplus Plutonium Disposition and the U.S. Policy of Reprocessing. Washington, DC: Department of Energy.

29. U.S. Department of Energy. Office of Fissile Materials Disposition, 1997.

Record of Decision on the Storage and Disposition of Weapons-Useable Fissile Materials Final Programmatic Environmental Impact Statement. Washington, DC: Department of Energy.

30. U.S. Department of State. 1970. Treaty on the Nonproliferation of Nuclear Weapons. United States Treaties vol. 21, pt. 1.

31. U.S. Department of State. 1996. Joint U.S.-Russian Plutonium Disposition Steering Committee. Joint United States/Russian Plutonium Disposition 
Study. Washington, DC: Department of State.

32. U.S. Nuclear Regulatory Commission. 1976. "Final Generic Environmental Statement on the Use of Recycle Plutonium in Mixed Oxide Fuel in Light Water Cooled Reactor." Washington, DC: Nuclear Regulatory Commission. NUREG-0002.

33. U.S. Nuclear Regulatory Commission. 1995a. "Potential Issues Regarding Use of MOX Fuel in Existing Operating Reactors." Washington, DC: Nuclear Regulatory Commission. Conference Record No. MD-95-007

34. U.S. Nuclear Regulatory Commission. 1995b. "MOX Fuel Issues Related to the DOE Fissile Materials Disposition Program." Washington, DC: Nuclear Regulatory Commission. Conference Record No. MD-95-002.

35. U.S. Nuclear Regulatory Commission. 1997a. Briefing by DOE on Plutonium Disposition. Washington, DC: Nuclear Regulatory Commission.

36. U.S. Nuclear Regulatory Commission. 1997b. Briefing by DOE on Plutonium Disposition Strategy and Program. Washington, DC: Nuclear Regulatory Commission.

37. Williams Jr., D. L. 1997. Licensing Issues Associated with the Use of Mixed-Oxide Fuel in U.S. Commercial Nuclear Reactors. Oak Ridge, TN: Oak Ridge National Laboratory. ORNL/TM-13421. 